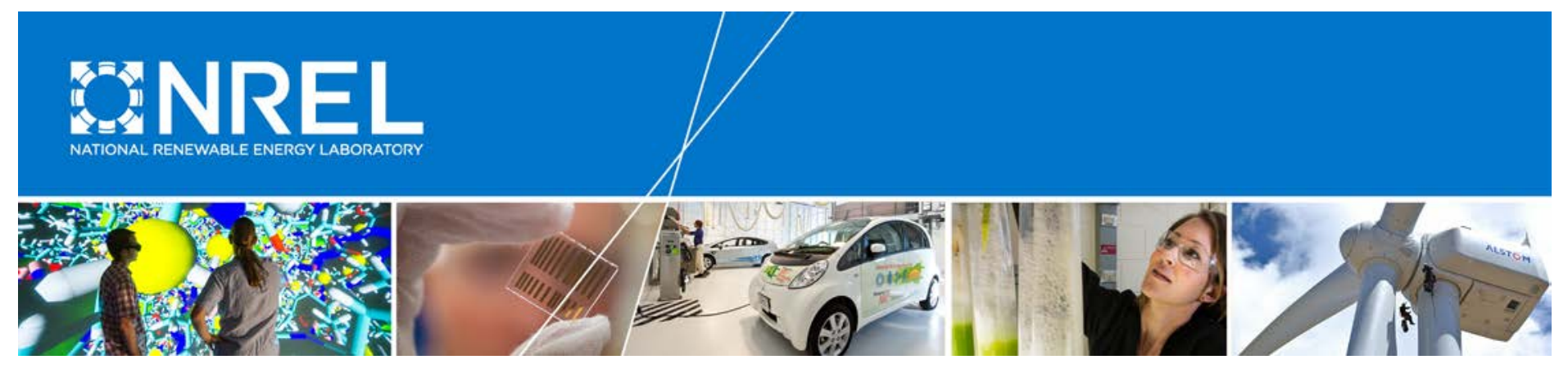

\title{
Historical and Current U.S. Strategies for Boosting Distributed Generation
}

Travis Lowder, Paul Schwabe, and Ella Zhou National Renewable Energy Laboratory

Douglas J. Arent Joint Institute for Strategic Energy Analysis

This work is a part of the China Grids Program for a LowCarbon Future, supported by the Children's Investment Fund Foundation.

NREL is a national laboratory of the U.S. Department of Energy Office of Energy Efficiency \& Renewable Energy Operated by the Alliance for Sustainable Energy, LLC

This report is available at no cost from the National Renewable Energy Laboratory (NREL) at www.nrel.gov/publications.

Technical Report

NREL/ TP-6A20-64843

August 2015

Contract No. DE-AC36-08GO28308 


\section{Historical and Current U.S. Strategies for Boosting Distributed Generation}

Travis Lowder, Paul Schwabe, and Ella Zhou National Renewable Energy Laboratory

Douglas J. Arent

Joint Institute for Strategic Energy Analysis

Prepared under Task No. ACTC.1340
National Renewable Energy Laboratory 15013 Denver West Parkway Golden, CO 80401

303-275-3000 • www.nrel.gov
NREL is a national laboratory of the U.S. Department of Energy Office of Energy Efficiency \& Renewable Energy Operated by the Alliance for Sustainable Energy, LLC

This report is available at no cost from the National Renewable Energy Laboratory (NREL) at www.nrel.gov/publications.

\section{Technical Report}

NREL/ TP-6A20-64843

August 2015

Contract No. DE-AC36-08GO28308 


\title{
NOTICE
}

This report was prepared as an account of work sponsored by an agency of the United States government. Neither the United States government nor any agency thereof, nor any of their employees, makes any warranty, express or implied, or assumes any legal liability or responsibility for the accuracy, completeness, or usefulness of any information, apparatus, product, or process disclosed, or represents that its use would not infringe privately owned rights. Reference herein to any specific commercial product, process, or service by trade name, trademark, manufacturer, or otherwise does not necessarily constitute or imply its endorsement, recommendation, or favoring by the United States government or any agency thereof. The views and opinions of authors expressed herein do not necessarily state or reflect those of the United States government or any agency thereof.

This report is available at no cost from the National Renewable Energy Laboratory (NREL) at www.nrel.gov/publications.

Available electronically at SciTech Connect http:/www.osti.gov/scitech

Available for a processing fee to U.S. Department of Energy and its contractors, in paper, from:

\author{
U.S. Department of Energy \\ Office of Scientific and Technical Information \\ P.O. Box 62 \\ Oak Ridge, TN 37831-0062 \\ OSTI http://www.osti.gov \\ Phone: 865.576.8401 \\ Fax: 865.576.5728 \\ Email: reports@osti.gov
}

Available for sale to the public, in paper, from:

\author{
U.S. Department of Commerce \\ National Technical Information Service \\ 5301 Shawnee Road \\ Alexandria, VA 22312 \\ NTIS http://www.ntis.gov \\ Phone: 800.553 .6847 or 703.605 .6000 \\ Fax: 703.605.6900 \\ Email: orders@ntis.gov
}




\section{Preface}

China now installs more renewable electricity each year than any other country in the world. Much of this is variable renewable electricity, especially wind and solar generation. A growing body of experience exists from around the world on how to plan and operate electricity grids with high penetrations of variable renewable electricity. China is actively contributing to this body of experience given the rapid growth in renewable electricity deployment there, while at the same time digesting experiences from other countries.

This report is part of a series describing technical collaboration between the National Renewable Energy Laboratory (NREL), the China National Renewable Energy Center (CNREC) along with other key research institutes in China, and the Danish Energy Agency. The collaboration focuses on sharing experiences in the planning, deployment and operation of high-penetration renewable electricity grid systems. The Children's Investment Fund Foundation in the United Kingdom is funding this five-year collaboration.

The core element of the collaboration during this first year was a series of expert engagements in China to share technical knowledge and experience on four key topics:

1. Comprehensive energy scenario design and modeling

2. Renewable energy (RE)-friendly grid development

3. Power system flexibility

4. Boosting distributed generation of RE.

These engagements built on and significantly expanded existing collaboration between the Danish Energy Agency and CNREC experts.

This report summarizes some of the issues discussed during the engagement on the fourth topic listed above. It focuses primarily on the business and investment models for distributed generation, limiting its discussion to the U.S. context by design. Exploration of whether and how U.S. experiences can inform Chinese energy planning will be part of the continuing project, and will benefit from the knowledge base provided by this report. We believe the initial stage of collaboration represented in this report has successfully started a process of mutual understanding, helping Chinese researchers to begin evaluating how lessons learned in other countries might translate to China's unique geographic, economic, social, and political contexts.

We look forward to continuing the collaboration for the remaining four years and building on these initial successes. 


\section{Acknowledgments}

The authors would like to thank the following people for their review and comments: John Barnett, Jaquelin Cochran, David Feldman, Jenny Heeter, Jeffrey Logan, and Patricia Statwick of NREL, and Hu Runqing of CNREC. This work is a part of the China Grids Program for a Low-Carbon Future, supported by the Children's Investment Fund Foundation. 


\section{Acronyms}

C\&I

CAGR

CNREC

DG

DGPV

FHFA

FiT

GW

GWh

HERO

ITC

$\mathrm{kW}$

$\mathrm{kWh}$

LCOE

MACRS

MW

NEA

NREL

O\&M

PACE

PPA

PUC

PV

REC

RMB

RPS

SREC

TPO

VOST commercial and industrial

compound annual growth rate

China National Renewable Energy Center

distributed generation

distributed generation photovoltaics

Federal Housing and Finance Agency

feed-in tariff

gigawatt

gigawatt-hour

Home Energy Renovation Opportunity

investment tax credit

kilowatt

kilowatt-hour

levelized cost of energy

modified accelerated cost recovery system

megawatt

National Energy Administration (China)

National Renewable Energy Laboratory

operations and maintenance

property assessed clean energy

power purchase agreement

public utility commission

photovoltaics

renewable energy certificate

renminbi (Chinese currency)

renewable portfolio standard

solar renewable energy certificate

third-party ownership

value of solar tariff 


\section{Table of Contents}

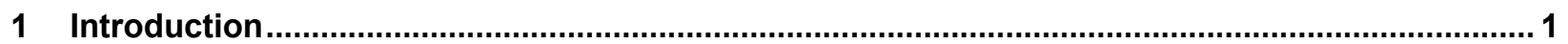

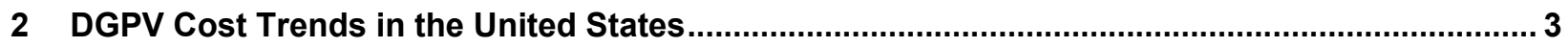

3 Federal, State, and Regulatory Policy in Support of DGPV ................................................... 6

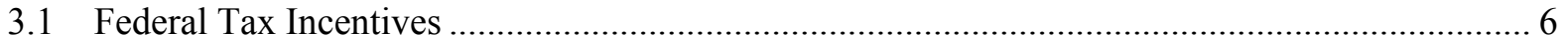

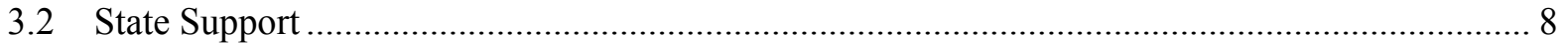

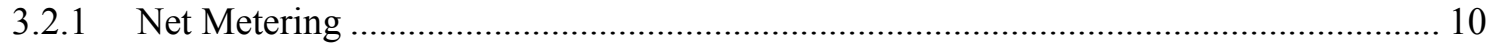

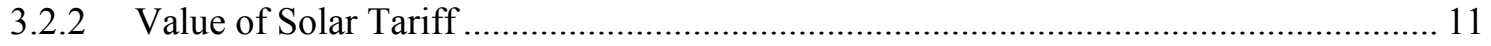

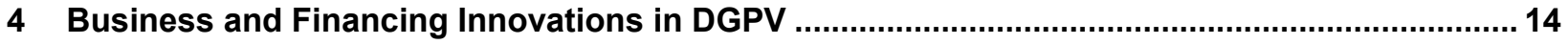

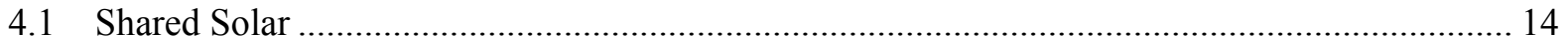

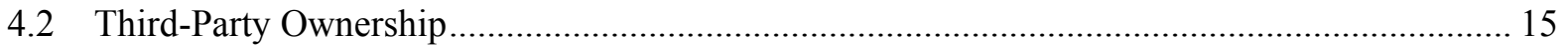

4.2.1 Third Party Ownership and Public Sector Procurement................................................ 17

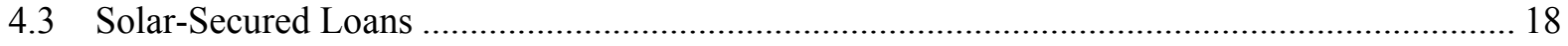

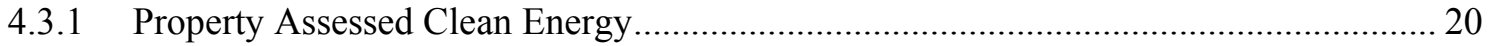

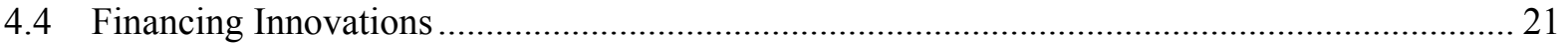

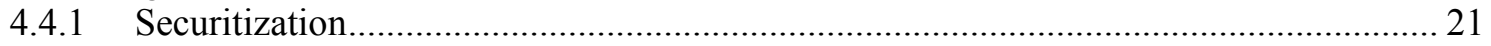

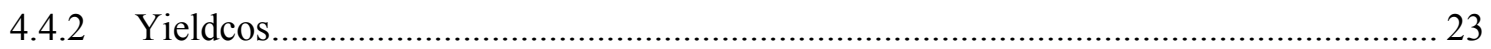

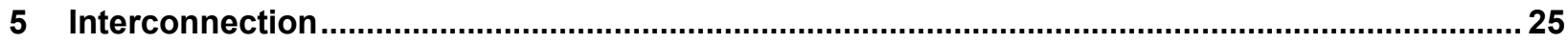

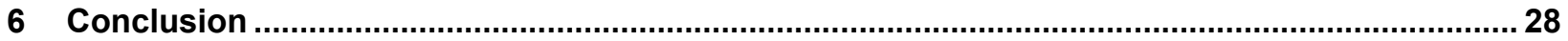

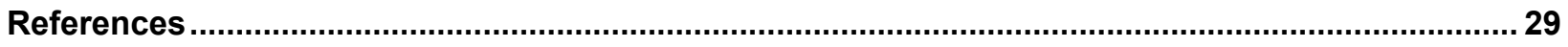

\section{List of Figures}

Figure 1. Annual and cumulative DGPV installations in the United States, 2008-2014 ........................ 4

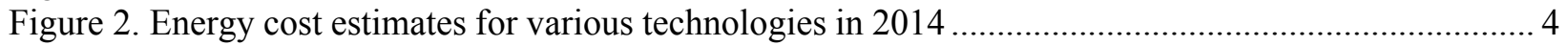

Figure 3. PV system cost trajectories by size in Arizona, California, Massachusetts, New Jersey,

Maryland, and New York, 2010-2015 ........................................................................ 5

Figure 4. Average residential and commercial retail rates across the United States ................................. 8

Figure 5. RPS with solar or DG provisions ............................................................................. 9

Figure 6. Process for PV building permitting and interconnection...................................................... 26

\section{List of Tables}

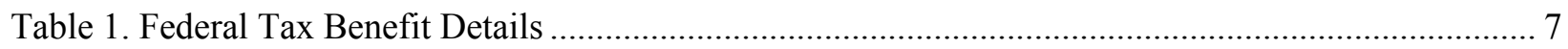

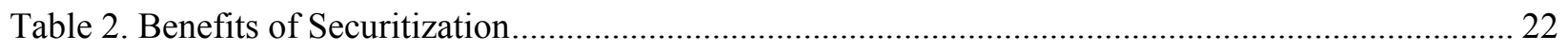




\section{Introduction}

China's solar photovoltaic (PV) industry is growing rapidly. In 2013, China produced 26 gigawatts (GW) of PV modules, over $60 \%$ of the world's total supply, and $43 \%$ of the modules were for domestic consumption (MIIT 2014). From a total installed capacity of 240 megawatts (MW) in 2010 to $28.05 \mathrm{GW}$ in 2014, solar PV is now providing $0.45 \%$ (25 gigawatt-hours [GWh]) of the country's entire electricity generation (NEA 2015). Since 2013, China has established a series of policies and guidelines to provide support for solar PV development, including a national feed-in-tariff (FiT) of renminbi (RMB) 0.42/kilowatt-hour (kWh). Despite this impressive rate of growth for the overall solar market in China, new distributed solar PV installation in 2014 still fell far short of the $8 \mathrm{GW}$ target proposed by the National Energy Administration (NEA). Challenges in financing and interconnection management have restrained the growth potential of distributed solar PV (CREIA 2015).

The distributed generation photovoltaic (DGPV) financing challenge in China in particular stems from several prominent issues including, but not limited to, project sizes that limit financing options; rooftop and land ownership issues; challenging distributed generation (DG) economics resulting from high capital costs and low competing electricity prices; and high financing costs resulting from perceived risks by capital providers, among others. First, the size of the DG projects is such that it is not small enough to be easily self-funded, but not big enough to attract capital market or fund investment. Second, China's rooftop and land ownership issues makes DG more challenging: residential projects often cannot move forward until consensus has been reached among all occupants of an apartment building; for commercial projects, the turnover of the business ownership is more frequent than the life of the solar project itself. As a result, there are difficulties in using the solar project as collateral to obtain a bank loan (Wang 2014). Third, low electricity prices can reduce the economic value of the DGPV system. Under the current DG policy in China, the rooftop solar owners would use the electricity generated from their solar panel first, and then sell the excess electricity back to the grid for the separate FiT rate. The low electricity rate of the residential sector in particular (which is lower than that of the FiT and in fact, lower than rate for the industrial and commercial sectors in China) diminishes the economic value of a residential DGPV system. So despite the relatively high FiT rate, the DGPV market in the residential sector has not taken off. Fourth, the financing cost for solar is high (generally above $8 \%$, sometimes reaching $10 \%-12 \%$ ) and also contributes to the challenging economics. Concerns over the quality of the solar panels and payment from the power consumer, who may move or go bankrupt during the duration of the loan, make the financing cost of DG projects high (Dai 2014).

In contrast to the Chinese experience, the DGPV market in the United States grew rapidly from under $2 \mathrm{GW}$ in 2009 to over $8 \mathrm{GW}$ by 2014 (Figure 1). The rise in DGPV in the United States has been driven by a number of factors including federal and state policy support mechanisms; business model and financing innovations; and risk reduction efforts. The rapid rise in DGPV in the United States, however, has introduced a new set of power sector challenges including electric utility disruption; rate redesign and associated ratepayer cost impacts; concerns over grid stability; and interconnection challenges.

This report seeks to describe a variety of top-down and bottom-up practices that, in concert with the macro-environment of cost-reduction globally and early adoption in Europe, helped boost the 
DGPV market in the United States. These experiences may serve as a reference in China's quest to promote distributed renewable energy. The structure of the rest of the report is as follows: Section 2 discusses recent trends in DGPV development in United States; Section 3 summarizes federal and state policy and regulatory support for DGPV; Section 4 analyzes the business and financing innovations in DGPV, including shared solar, third-party ownership, securitization, and yieldcos; Section 5 briefly discusses interconnection standards and procedures; and finally the report concludes with some key lessons learned through the development of the DG in the United States. 


\section{DGPV Cost Trends in the United States}

DGPV in the United States is generally defined as solar PV capacity installed on or near the site of load (rooftop and ground-mounted), interconnected at the distribution level on the utility grid, and typically less than $1 \mathrm{MW}$ in size (SEIA 2015; Gauntlett and Lawrence 2015). DGPV is most commonly used to offset electricity usage for utility customers who typically do not sell energy into the wholesale markets. Accordingly, DGPV in the United States competes with retail electric rates; this has made it an economic option in several states with relatively high prices for electricity.

In the United States, the DGPV category encompasses two sectors of the solar market: residential (with system sizes typically ranging up to $25 \mathrm{~kW}$ ) and commercial (25 kW-1 MW). ${ }^{1}$ Combined, these two market segments have grown rapidly over the last seven years, exhibiting a compound annual growth rate (CAGR) of nearly $42 \%$ (see Figure 1$)^{2}$

\footnotetext{
${ }^{1}$ Some analysts divide the commercial market into "small commercial" $(25 \mathrm{~kW}-250 \mathrm{~kW})$ and "commercial and industrial," or C\&I (250 kW - 1,000 kW) segments. For simplicity, this report will combine both commercial and C\&I as well as installations for public sector entities that fall within this size category (e.g., municipalities, nonprofits, universities, etc.). Typical project sizes for each sector listed in this report are based on interviews with solar industry professionals.

${ }^{2}$ It is worth noting that, in 2014, the U.S. commercial solar market had its first down year since the beginning of the $21^{\text {st }}$ century. This resulted from several barriers unique to commercial solar, including declining state incentives and financing challenges such as: 1) the high transaction costs of executing a solar deal, which can limit investor returns in the smaller commercial deals; and 2) a lack of standardization in contracts and deal structures, which can slow development timelines and make project aggregation difficult. Many power purchase agreement counterparties in the commercial market are also unrated, meaning that an expensive diligence process is typically required to ascertain their creditworthiness and satisfy investor concerns.
} 


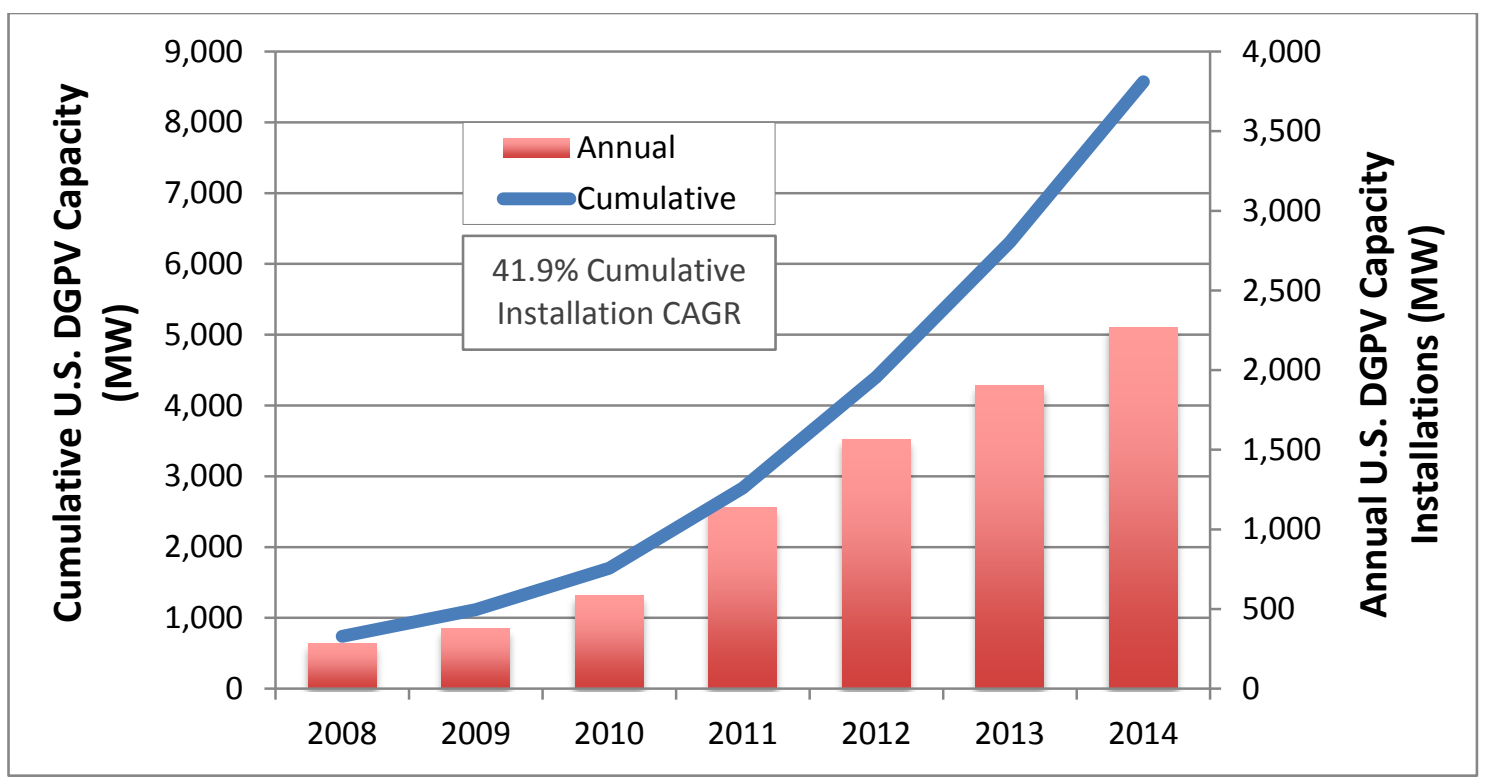

Figure 1. Annual and cumulative DGPV installations in the United States, 2008-2014

Source: GTM/SEIA 2015

Since 2008, a combination of plummeting polysilicon prices, rapidly growing global PV markets, and increasing module supply has driven an unprecedented reduction in the cost competitiveness of solar PV technologies. Today, the PV levelized cost of energy (LCOE) (one approximate measure of competitiveness) can be competitive with conventional sources of electricity. Figure 2 provides LCOE estimates from a variety of generation technologies as estimated by the financial firm Lazard (Lazard 2014). The two DGPV categories ("Solar PVRooftop Residential" and "Solar PV-Rooftop C\&I") are two of the higher cost generation options in this analysis (note these are "unsubsidized" LCOE numbers), and their ranges are in line with retail rates in some states, particularly after state and federal incentives are factored in.

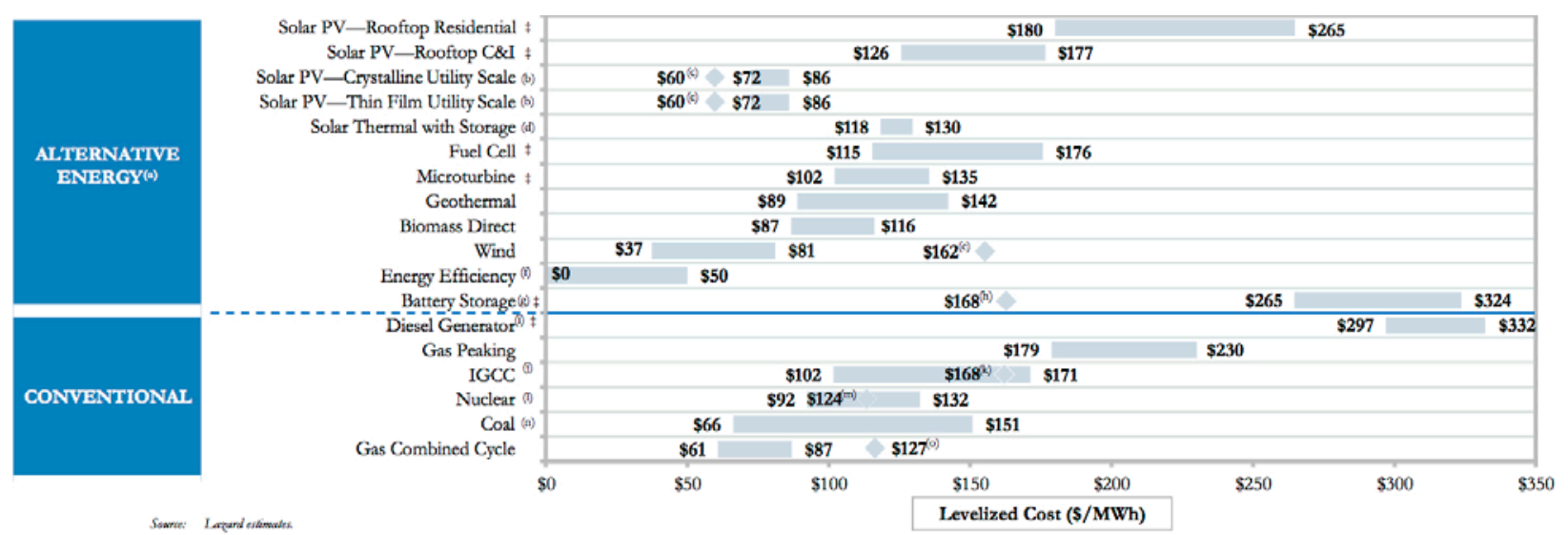

Figure 2. Energy cost estimates for various technologies in 2014

Source: Lazard 2014

In light of a dynamic cost structure environment in the United States and globally, PV prices have continued to remain cost competitive in many market segments. Some analysts forecast that module prices will actually decline by $8 \%$ year-over-year in 2015 (Jones 2015). 
Aside from the module, soft costs, such as customer acquisition, permitting, inspection, interconnection, installation labor, and financing, amount to over half of the total installed cost of DGPV systems (DOE 2014). Soft costs can vary significantly depending on the market and be a driver of state-by-state disparities in dollar-per-watt system prices. However, even given these disparities, cost trajectories are edging downward in all states; representative examples are shown in Figure 3.

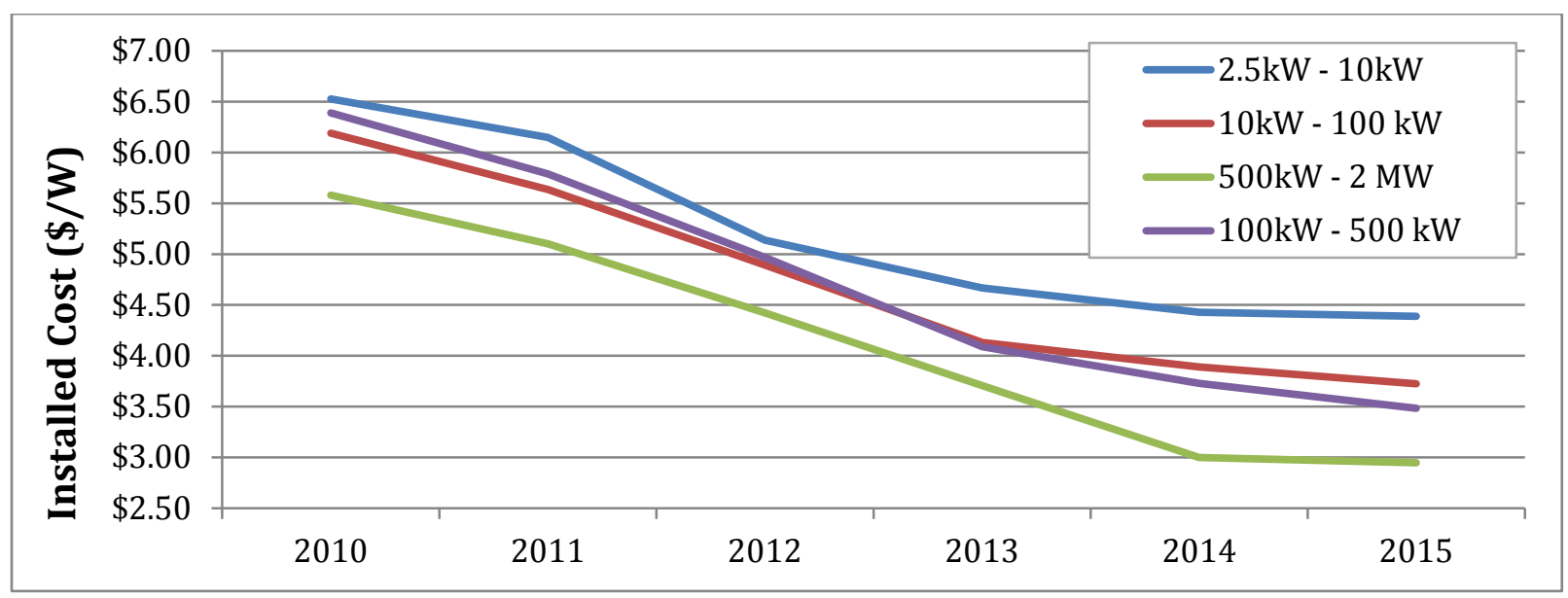

Figure 3. PV system cost trajectories by size in Arizona, California, Massachusetts, New Jersey, Maryland, and New York, 2010-2015

Source: NREL internal data, based on state incentive programs

Falling costs of PV modules as well as other system level components have not only allowed for reductions in PV LCOE, but also for a reduction in state-level incentives without major disruptions in many state markets. Alternative means of financing have emerged to further lower the PV system prices through financing cost reduction and contributed to the rapid growth of DG PV in the United States.

\footnotetext{
${ }^{3}$ The number and costs of the installations represented in this chart vary considerably by project and by state. The numbers in this chart are the median installed costs across the selected states and therefore do not portray the highest or lowest extent of the range.
} 


\section{Federal, State, and Regulatory Policy in Support of DGPV}

PV has been a commercial technology in the United States since the 1950s, although only within the last five years has it begun to comprise an appreciable portion of the annual capacity growth in the U.S. electricity sector. For much of its commercial history, the capital cost associated with PV installations has been too high for the electricity they generated to be competitive with conventional forms of energy production. These unfavorable economics were a principal barrier to the growth of PV in the electricity sector. In the mid-2000s, under the backdrop of early adoption in Europe and PV cost reductions globally, the U.S. federal government made available a $30 \%$ tax credit and states such as California implemented incentive programs to drive deployment within their jurisdictions, and PV economics began to attract investors in the United States. ${ }^{4}$ This section will discuss the incentives federal and state governments have used to support the deployment of PV.

\subsection{Federal Tax Incentives}

Federal incentives for renewable energy deployment in the United States are currently delivered through the U.S. tax code (Bolinger 2014). The two tax incentives to which PV solar has access today are the investment tax credit (ITC) and an accelerated depreciation schedule (known as the modified accelerated cost recovery system, or MACRS) for businesses. ${ }^{5}$ The ITC allows investors to receive a credit valued at $30 \%$ of the qualifying solar project costs on their income tax liability (the amount owed to the federal government at the end of the tax year). MACRS allows investors to depreciate their qualifying basis in the solar project by $100 \%$ in the first six years of operation. This accelerated depreciation schedule generates taxable losses in the first five years of a project, and these can be applied as a deduction against taxable income. Taken together, the MACRS and ITC can account for over $50 \%$ of the capital costs of a project (Chadbourne \& Parke 2008). Table 1 shows a breakdown of each incentive.

\footnotetext{
${ }^{4}$ PV module prices also began falling precipitously in 2008 owing to growth in silicon supply and expanding markets in Europe - namely Germany, Spain, and Italy — as a result of FiT schemes.

${ }^{5}$ The $30 \%$ ITC was originally made available to solar projects through the 2005 Energy Policy Act. After two extensions, via other pieces of legislation, the credit is set to scale down to $10 \%$ on January 1, 2017, for businesses and expire completely for homeowners. Regarding MACRS, the current iteration of the accelerated depreciation schedules for various types of equipment has been implemented since 1986, and there is no scheduled expiration. However, there has been talk among U.S. lawmakers that MACRS may be modified or discarded with any overhauls to the U.S. tax code (Chadbourne \& Parke 2013).
} 
Table 1. Federal Tax Benefit Details

\begin{tabular}{|c|c|c|}
\hline & ITC & Accelerated Depreciation \\
\hline Value & $\begin{array}{l}\text { Tax credit of } 10 \% \text { or } 30 \% \text { of project } \\
\text { costs, depending on technology }\end{array}$ & $\begin{array}{l}\text { Depreciation of eligible costs (not all } \\
\text { project costs qualify) }\end{array}$ \\
\hline $\begin{array}{l}\text { Select } \\
\text { Qualifying } \\
\text { Technologies }\end{array}$ & $\begin{array}{l}\text { Solar } \\
\text { Fuel cells } \\
\text { Small wind } \\
\text { Geothermal }\end{array}$ & $\begin{array}{l}\text { Various types of business equipment, } \\
\text { including renewable energy }\end{array}$ \\
\hline Cost Basis & $\begin{array}{l}\text { Eligible project costs. Credit taken at } \\
\text { the time the project is placed in } \\
\text { service. Can be combined with } \\
\text { accelerated depreciation }\end{array}$ & $\begin{array}{l}\text { If taken with the ITC, the basis is reduced } \\
\text { by half the value of the credit (i.e., 15\%) }\end{array}$ \\
\hline Expiration & $\begin{array}{l}\text { To receive the } 30 \% \text { Section } 48 \text { ITC, } \\
\text { the project must be placed in service } \\
\text { before } 1 / 1 / 2017\end{array}$ & None \\
\hline
\end{tabular}

The sizes of renewable energy deals are such that the received 30\% ITC can be too large for companies with limited tax capacity to absorb in one year. Any portion of the credit unused in the first year can be carried forward into future tax years, but this reduces the value of the credit because of the time value of money. Moreover, to maximize the value of the MACRS deductions in conjunction with the ITC, companies will require even larger tax capacities - so large in fact that very few renewable energy developers can take advantage of them.

Accordingly, developers will seek tax equity investors to commit capital to their projects and thereby monetize the value of the tax incentives. Tax equity investors are typically large U.S. banks and financial firms, although there are some corporations that also participate in this space (e.g., Google). They invest in complex project financial structures that are configured to enable their receipt of the tax benefits. Common after-tax rates of return for tax equity investors as of this writing are around $8 \%-10 \%$ for unlevered (i.e., no project-level debt) deals (Chadbourne \& Parke 2015). Tax equity is an expensive form of financing because it is highly complicated and requires the expertise of attorneys, investment banks, and others to execute. Even at high rates of return, however, tax equity does allow developers to capture the value of the tax incentives and pass these savings on to the end-user through a reduced cost of solar energy.

The federal tax incentives are the enabling force behind third party ownership (TPO, described in Section 4.2), which has been a major growth engine of DGPV since 2008. TPO has allowed homeowners and businesses to install solar on their property for little or no money down and reap the cost reduction benefits of the tax incentives without engaging in the complexities associated with monetizing them. 


\subsection{State Support}

DGPV growth has not been spread evenly across all fifty U.S. states. It is instead concentrated in states with favorable characteristics, including the local price of electricity, the policy and regulatory environment, and, often but not always, the solar resource (i.e., the amount of sun).

Regional electricity prices within a utility service territory are a major driver of the economics of DGPV. If a PV system can offer electricity at a price that is equal to or less than the local utility rate, then consumers and businesses in that particular utility service territory may have an incentive to offset their energy usage with DGPV. Because DGPV competes with the retail price of energy, which is higher than the wholesale price utilities are charged by independent power producers in the power markets, selling directly to consumers allows smaller distributed systems to offer competitive energy prices to hosts. ${ }^{6}$ See Figure 4 for a breakout of average retail rates for residential and commercial customers in the United States.
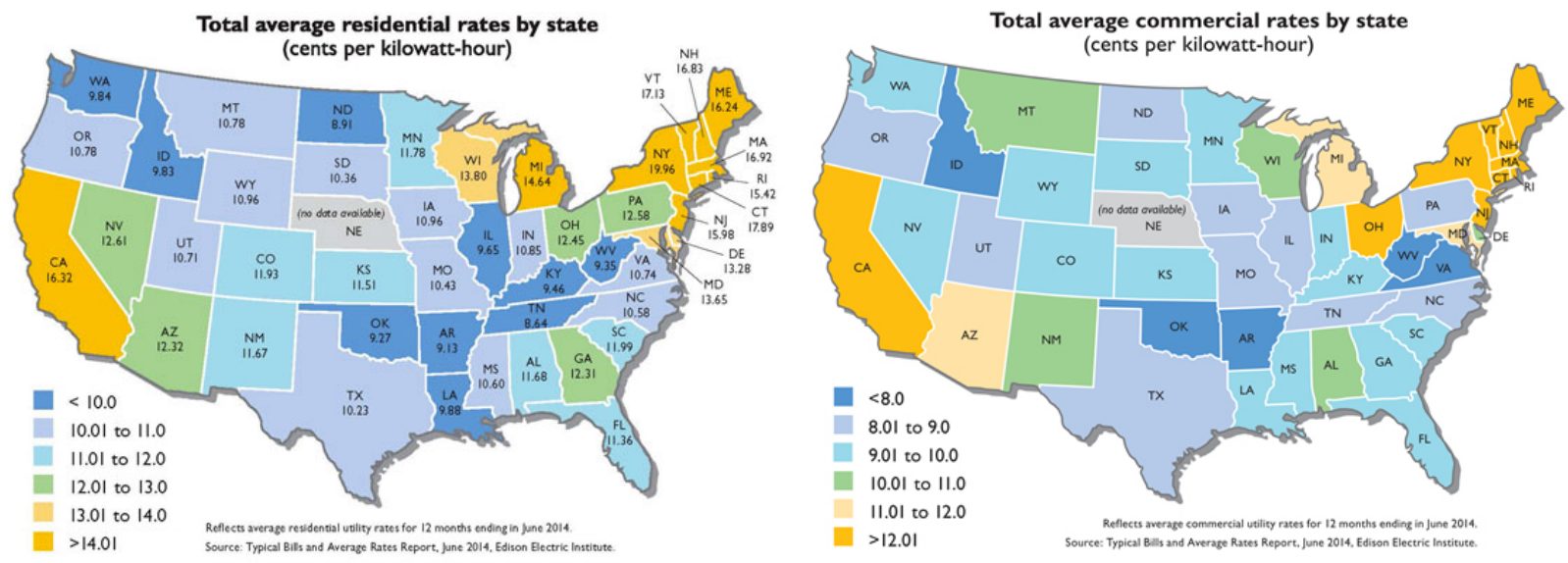

Figure 4. Average residential and commercial retail rates across the United States

Source: Pacific Power 2014, using Energy Electric Institute data on typical bills and average rate reports

To drive DGPV economics to the point where the technology can compete with retail rates, many U.S. states have employed a suite of policy or incentive schemes as a complement to the federal tax benefits. Some policies that have been particularly successful in bolstering the growth of DGPV at the state level include:

- Renewable portfolio standards (RPS): These mandates require that a certain amount of generation from specified power producers and load-serving entities derive from renewable resources. Typically, lower-cost renewables like wind and biomass are used to

\footnotetext{
${ }^{6}$ Residential electricity prices in the United States were, on a national average, between $10 \%-15 \%$ higher than commercial prices from 2014 - 2015 (EIA 2015). Additionally, commercial rates are more complicated and often contain "demand charges," which are not as readily offset by PV productions as is variable energy usage. Accordingly, commercial PV must capture additional cost efficiencies relative to residential PV in order to remain competitive in its market. As of February 2015, the state of Hawaii had the highest rates for commercial and residential electricity at $\$ 0.30 / \mathrm{kWh}$ and $\$ 0.27 / \mathrm{kWh}$, respectively. Washington State had the lowest residential rates $(\$ 0.08 / \mathrm{kWh})$ and Oklahoma had the lowest commercial rates $(\$ 0.07 / \mathrm{kWh})$ (EIA 2015).
} 
meet RPS requirements. Recognizing this, more than $75 \%$ of jurisdictions with an RPS also have a solar or DG carve-out provision (22 states and Washington, D.C., illustrated in Figure 5), an increase from only nine of 22 RPS jurisdictions in 2007 (38\%) (DSIRE 2015a; Wiser 2007). These provisions require that a certain percentage of retail sales come from solar or DG resources, and, to date, have been a large driver of solar/DG in the United States. Lawrence Berkeley National Laboratory (LBNL) (Barbose 2014) estimated that solar/DG set-asides were responsible for $60 \%-80 \%$ of non-California PV additions from 2005 to 2014 . $^{7}$

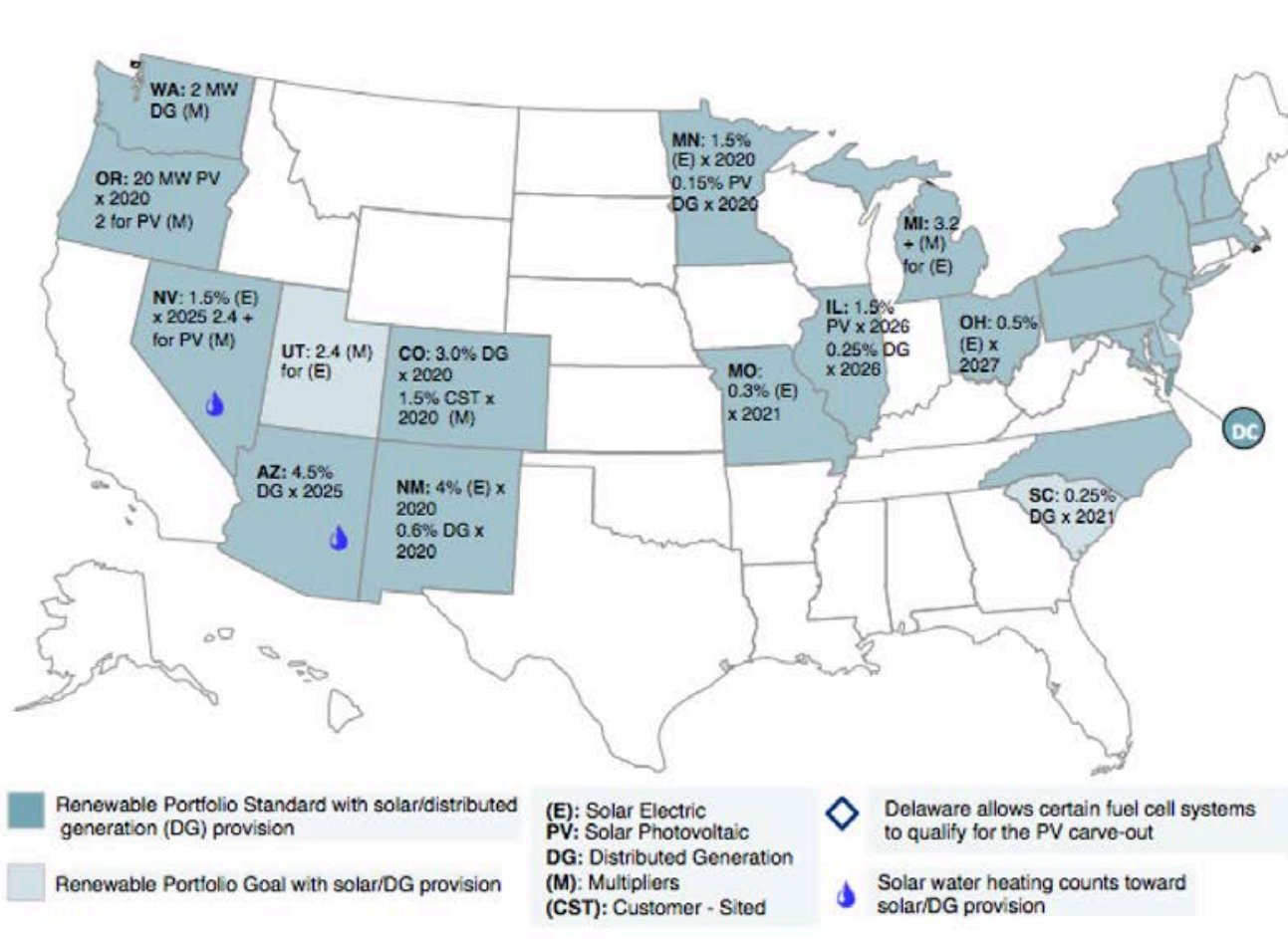

VT: $1 \%$ DG X $2017+3 / 5$ ths of $1 \%$ /year until $10 \%$ X 2032 NH: $0.3 \%$ (E) $\times 2014$ MA: 400 MW PV $\times 2020$ NY: $0.58 \%$ customer sited $\times 2015$ PA: $0.5 \%$ PV $\times 2021$ $\mathrm{NJ}: 4.1 \%$ (E) $\times 2028$ DC: $2.5 \%$ (E) $\times 2023$ DE: $3.5 \%$ PV $\times 2026$ 3.0 (M) for PV MD: $2 \%$ (E) $\times 2020$ NC: $0.2 \%$ (E) $\times 2018$

Figure 5. RPS with solar or DG provisions

Source: DSIRE 2015b

- Renewable energy certificates and solar renewable energy certificates (RECs and SRECs): These tradable certificates are produced as per the provisions of the RPS, and represent the "environmental attributes" of renewable generating facilities. These certificates are typically valued by market dynamics and purchased by generators, utilities, and load serving entities that must comply with the RPS. The amount of RECs or SRECs owned by a given entity will determine its level of compliance with the portfolio standard requirements for a given period. Other entities such as businesses and

\footnotetext{
${ }^{7}$ Although an exact figure for how much DGPV (as opposed to utility-scale PV) is supported by solar carve-outs is unavailable, NREL has found that residential and commercial PV in states with a carve-out represented $60 \%$ of the non-California residential and commercial PV market in the United States (NREL analysis using data from Navigant [2015]).
} 
even consumers may purchase RECs and SRECs if they have goals to drive renewable generation or offset their carbon footprint.

- Net Metering: This policy has been foundational to every DGPV market in the United States and is discussed in detail in Section 3.2.1 along with value of solar tariffs.

- Production and cost-based incentives: These are both mechanisms by which owners of renewable generation can receive payments either based on the amount of kilowatt-hours a system generates (production-based incentive) or on the cost to install a system (costbased incentives). These payments can improve the resulting price of electricity from a renewable generator (thus making it more competitive with traditional sources) and also accelerate investor payback.

- Tax credits: Some states have opted to extend tax credits to renewable generation facilities in addition to those offered at federal level. To efficiently take advantage of these credits, businesses must have sufficient state income tax liability to offset with the tax credit.

- Property Assessed Clean Energy (PACE): States can pass legislation to allow counties and municipalities within their jurisdiction to levy special tax assessments (sometimes called "benefit assessment liens") on residential and commercial real estate. These assessments can then be capitalized by loans originated either through tax-exempt bonds or from third-party lenders (which is more common). The funds from these loans can be paid directly to a contractor or to the property owner for the purpose of installing energy efficiency and renewable energy upgrades. Property owners repay the loan plus interest through an increase in their property taxes amortized over an extended period (e.g., 20 years). See Section 4.3.1 for more on PACE.

In the recent past, state incentives were critical to the economics of PV for commercial and residential electricity purchasers. However, PV component and system costs have fallen such that, in some states or municipalities, no incentives are necessary beyond the federal tax benefits to drive favorable DGPV economics.

\subsubsection{Net Metering}

Net metering is a state- and sometimes utility-level policy that, in essence, allows renewable energy system hosts to "spin their meter backwards." In other words, if the host's energy generation exceeds their load, the excess electricity will be sent back to the grid (i.e., spinning the meter backwards) and the host will receive a credit for unused energy which is applied to energy they purchased from the grid. In the U.S. residential market, people are typically away from their homes during the day while the solar resource is strongest, and will return home in the evening as the resource is waning. Net metering allows for the periods of high generation and low electricity use to offset periods of low generation and high electricity use.

Forty-four states and Washington, D.C. have a net metering policy in place (DSIRE 2015a), though policy structures vary. The rate at which renewable electricity is credited is one such variance, but in the largest U.S. solar markets, it is commonly pegged to the full retail rate. In other words, if the homeowner in the example above were paying $\$ 0.15 / \mathrm{kWh}$ to purchase electricity from the utility, then the electricity produced by the PV system that is fed onto the grid (i.e., not consumed by the homeowner) would be credited at the same $\$ 0.15 / \mathrm{kWh}$. Some 
states offer credits for renewable generators at a lower rate than retail. A value of solar tariff (VOST), which has been adopted in the city of Austin, Texas, and in the state of Minnesota, can actually value credits at a level above the retail rate (see Section 3.2.2).

Net metering has been a major driver of DGPV deployment, allowing hosts to unlock the full economic value of their systems (Black 2009). However, it has come under criticism recently for creating a "cross subsidy." That is, because solar customers are paying lower electricity bills under net metering regimes, utilities with a large portion of solar customers are faced with a shrinking customer base from which to recoup their fixed costs (e.g., the costs associated with maintaining the transmission and distribution infrastructure). Utilities have argued that solar customers do not pay their fair share to maintain the grid, and the fixed costs are being unevenly allocated to the non-solar customers in the service territory (Wellinghoff and Tong 2015).

This argument has gained traction at the state public utility commission (PUC) and legislative levels, and by the end of 2014 there were over 20 ongoing proceedings that were examining either net metering or rate design to ensure that utilities could protect themselves against the adverse cost implications of high penetrations of customer-sited solar (GTM/SEIA 2015). Options proposed by utilities, PUCs, and state governments to deter some of these implications include:

- Including fixed charges on solar customers' bills. California and Arizona - the two biggest U.S. solar markets - have both approved minimal fixed charges as of this writing, though Arizona utilities are pursuing higher charges (Wesoff 2015).

- Reducing the net metering credit.

- Adopting a VOST. The city of Austin, Texas, and the state of Minnesota have both developed their own VOSTs (though in Minnesota, the utility has the option to choose between paying the customer the net metering credit or the VOST).

- Redesigning rates. There are several options for utilities to ensure that they continue to recover costs in service territories where DGPV is reaching high penetrations.

- Imposing a minimum bill, i.e., where utility customers must pay a certain amount every month even if they offset all of their electricity usage with a solar system.

- Allowing for utility ownership of solar assets. Two Arizona utilities have approval from their PUC to begin pilot programs to install solar on customer rooftops or as shared solar systems (see Section 4.1) and offer either bill credits or long-term fixed electricity rates.

- Transitioning utilities to be aggregators of distributed energy resources for delivery to grid operators. Under this scheme, embodied in New York State's Reforming the Energy Vision, utilities would be the interface between a distributed resources market and the Independent System Operator, the entity that ensures the operation and reliability of the grid (State of New York 2015).

\subsubsection{Value of Solar Tariff}

VOST schemes have been proffered as alternatives to net metering, offering credits that are calculated to reflect the monetary value of solar energy rather than credits pegged to the retail rate (Taylor et al. 2015). Operational examples of these policies are limited to date (as 
mentioned, only two jurisdictions in the United States have adopted them: the city of Austin, Texas, and the state of Minnesota), but there is a fair amount of interest in this type of scheme as a potential replacement to the embattled net metering policy in its current incarnation.

The innovation of the VOST scheme is that it seeks to quantify the value of solar energy. The tariff is calculated by determining the services that DGPV provides to the grid and to utilities, and then applying a valuation methodology (which can range from simple calculations of aggregated data to complex power system modeling analysis). Other assumptions about useful system life and expected generation also affect the calculation. The particular services that a VOST scheme contemplates can be a matter of debate. Services that are generally accepted among utilities, the solar industry, and other stakeholders include:

- Energy

- Generation capacity

- Transmission and distribution capacity

- System loss avoidance

- Ancillary services (frequency regulation, spinning and non-spinning reserves, etc.).

Other services the VOST could contemplate are:

- Fuel price hedge

- Market price response (i.e., DGPV generation reduces overall energy demand in the system, and therefore reduces the spot price)

- Environmental (carbon pollution reduction, air and water quality, etc.)

- RPS compliance

- Security, reliability, and grid resiliency

- Social (economic development) (Hansen and Lacey 2013).

Based on which of these services are included and the price at which they are valued (and the assumed life of the PV system, expected generation, cost of the system, and other factors), VOSTs can theoretically have wide ranges. Rocky Mountain Institute published a summary of 16 "value of solar" studies in 2013 entitled A Review of Solar PV Benefit \& Cost Studies (Hansen and Lacey 2013). The average values published in these reports (some were specific to certain markets, while others took a more comprehensive approach) ranged from $-\$ 0.18 / \mathrm{kWh}$ to almost $\$ 0.34 / \mathrm{kWh}$. Such variation suggests that the valuation of DGPV for the purposes of adequate compensation is still a novel approach that is highly sensitive to non-standardized assumptions. In addition to the Rocky Mountain Institute overview, the NREL technical report Methods for Analyzing the Benefits and Costs of Distributed Photovoltaic Generation to the U.S. Electric Utility System provides a valuable "how to" resource for calculating the value of solar energy (Denholm et al. 2014). 
Both Austin's and Minnesota's ${ }^{8}$ schemes stipulate that the tariff will be periodically reevaluated and is subject to change, which places price risk on DGPV hosts. In Minnesota's scheme, this risk is not borne by existing VOST subscribers because they lock in the VOST rate for 20 years on the date they execute their contract. Therefore, negative changes to the VOST would only impact future customers. In Austin, all DGPV customers - existing and future-receive the prevailing rate (recalculated annually) and do not have access to past rates. However, the scheme also includes a price floor at the retail rate. ${ }^{9}$

\footnotetext{
${ }^{8}$ Minnesota's VOST has not been implemented because utilities are given a choice between maintaining the current net metering structure or moving over to the VOST, which, in its current version, stipulates a higher remuneration for solar energy than the retail rate.

${ }^{9}$ Minnesota's scheme also has a price floor at the retail rate, but only for the first three years after the PUC approves the tariff (DSIRE 2015c).
} 


\section{Business and Financing Innovations in DGPV}

Business and financial model innovations have proliferated in the United States to take advantage of favorable policies and regional electricity prices described earlier. These innovations have contributed to the rise of DGPV in the United States and include developments such as shared solar systems, third party ownership, securitization and other financing mechanisms. Each of these is described in more detail below.

\subsection{Shared Solar}

According to an NREL analysis, approximately $75 \%$ of U.S. rooftop area is not suitable for solar PV installations (Denholm and Margolis 2008). Shared solar, which is a large offsite solar installation that can be shared by multiple electricity purchasers, could therefore drastically expand the DGPV market beyond its natural constraints. In shared solar-commonly referred to as "community solar" or "solar gardens"-_businesses and households own, lease, or subscribe to a portion of a commercial-sized PV or other renewable power system located locally, but not on their own premises. They are compensated by the utility through virtual net metering, which uses their proportional share of the PV generation to offset their individual electricity consumption. The PV system can be hosted and administered by utilities, businesses, local governments, nonprofit organizations, or a combination thereof. The project may be located on public buildings, private land, brownfields, or any location with suitable solar resources. Shared solar projects can be jointly owned or financed through third-party financing or direct utility financing (Ardani et al. 2013). Research shows that shared solar could represent 32\%-49\% of the U.S. distributed PV market in 2020, representing \$8.2-\$16.3 billion of cumulative investment (Feldman et al. 2015).

In a utility-sponsored model, a utility owns or operates a project that is open to voluntary ratepayers. The subscribers are able to offset personal electricity use without going to the effort of installing PV systems on their own rooftops. The subscriber may enroll through a single upfront payment or an on-going subscription fee to the solar project (Coughlin et al. 2010). Eleven states and the District of Columbia have enacted policies to allow shared renewable energy, and some of these states require certain regulated utilities to develop shared renewable energy.

In the United States, electric co-ops, municipal utilities, and public utility districts are exempted from federal income taxes, and therefore cannot benefit from the federal tax incentives described in Section 3.1. Thus in some cases, a special purpose entity is established to utilize the tax incentives available to commercial renewable energy projects. As in the utility-sponsored model, the special purpose entity would handle construction, management, and operation and maintenance (O\&M). The shared solar participants may own or lease part of the renewable power plant and receive credits on their electric bills. 


\section{Case Study: Shared Solar in Colorado}

The Colorado State Legislature passed the Community Solar Gardens Act in 2010, and the Colorado PUC adopted final rules for the development of the gardens in September of 2012. Under the Colorado rules, a community solar garden is defined as a $2 \mathrm{MW}$ or less rooftop or ground-mounted solar electric generation facility with at least 10 subscribers. Each subscription should be "at least one kW of the community solar garden's nameplate rating and supply no more than $120 \%$ of the community solar garden subscriber's average annual consumption of electricity..." The $1 \mathrm{~kW}$ rule does not apply to low-income subscribers.

Compensation to the subscriber takes the form of a virtual net metering credit against the subscriber's bill from the utility. The PUC sets the minimum and maximum purchase requirement of electrical output from community solar gardens for the utilities, currently at a minimum of $6 \mathrm{MW}$ per year. In addition, the PUC requires utilities to reserve at least $5 \%$ of their community solar garden acquisition budget for low-income subscribers (CCR 723-3).

In 2012 and 2013, Xcel Energy, Colorado's biggest utility with more than 1 million customers, approved the construction of 25 community solar projects totaling $118 \mathrm{MW}$ of capacity (Xcel Energy 2015). Xcel pays community solar customers approximately 7 cents per kilowatt for the generated power (Proctor 2014).

Two of the most active developers of community solar in Colorado in the recent years are the Clean Energy Collective and SunShare. The Clean Energy Collective offers an up-front ownership model, in which the customer - a business or an individual-buys a portion of a community renewable energy project with either cash or by taking out a loan and signs an agreement typically 20 years in length. The Clean Energy Collective handles everything from construction to operation and maintenance of the community renewable energy project, and the customers receive a monthly credit on their electric bills. SunShare offers a 20-year agreement for the customers to purchase the energy, rather than the panels, from the local community solar project to offset their electricity bills, without an up-front investment. Similar to the Clean Energy Collective, SunShare also builds, maintains, and manages the community solar project.

Under both models, bulk buying of the panels and other equipment, as well as unified construction lowers the system cost compared to that if the customers were to install their individual rooftop systems, and professional maintenance and possibly better siting make the system more cost effective. In addition, anyone with an electric bill is eligible to participate, thus opening up the possibility of solar ownership to renters, leasers, and a variety of businesses and individuals. Because there is no direct electric connection from the customer's premise to the solar panels, if the customer moves before the terms of the agreement, the energy credits will transfer to the new address, provided the customer is moving within the same county of the utility service area. Otherwise the system owner can resell the panel ownership (in the Clean Energy Collective model) or the energy (in the SunShare model) to another customer in the same area.

\subsection{Third-Party Ownership}

One of the primary drivers of DGPV in the United States is the development of the third party ownership model for solar. In the TPO model — which has largely been enabled through net metering policies and the availability of federal tax incentives-solar developers/investors retain ownership of the assets that they build and sell access to these assets under long-term contracts. In DGPV, the counterparties in these contacts are typically the system hosts, i.e., they own the roof or property on which the PV is installed, and they use the electricity generated from the PV system to offset their usage of energy from the grid. The two types of contractual arrangements by which purchasers may access the solar assets are a power purchase agreement (PPA), whereby a charge is assessed per each unit of energy generated, or a lease arrangement, whereby 
the host pays a fixed monthly lease fee. It is a common industry practice to escalate PPA rates and lease prices by a certain percentage (2\%-3\% is a typical range) for each year of the contract.

Contracting for power purchases via a PPA was a standard practice in the conventional power industry before the first solar PPA was pioneered by SunEdison in the mid-2000s. ${ }^{10}$ Shortly after SunEdison began executing long-term solar energy contracts (10-20 years, although 20 is the more common term today) with U.S.-based retailers such as Whole Foods and Staples, companies such as SolarCity and Sunrun that focused on residential installations began launching their businesses (Behar 2009). Today, TPO represents the majority of residential installations in the United States (72\% in 2014) and a significant portion of the commercial market as well (Munsell 2015). ${ }^{11}$

One of the principal advantages of TPO - sometimes referred to as the "solar as a service" model - has been the payment structure. TPO allows homeowners, businesses, and other wouldbe solar customers to install PV on their property without paying the upfront costs associated with installation. The cost of the project is instead amortized over its contracted life through periodic payments made by the host to the system owner.

The TPO model works particularly well in the United States because it makes good use of the tax benefits (the ITC and MACRS) by directing them to an entity that can efficiently benefit from them. That is, the project can be owned by a taxable entity that can take advantage of the full benefits in the years in which they occur, thus maximizing the time value of money. Moreover, some entities such as schools, nonprofits, and federal agencies are exempt from federal income tax, which means they are prohibited from using the ITC and MACRS as per the U.S. tax code (i.e., they have no federal tax liability to credit and no taxable income from which to deduct). Therefore, instead of buying solar projects and forgoing the $50 \%-60 \%$ cost reduction available through the tax benefits, tax-exempt entities may elect to have a taxable third-party own the project and pass through the value afforded by the credits via a reduced price of energy or a reduced lease payment.

An additional advantage of TPO is that the PV owner, not the host, retains responsibility for O\&M. And, because its cash flows derive directly or indirectly from the performance of the plant, the owner has an incentive to keep the asset functioning at an optimal level. This relieves the host, who will likely not have the appropriate resources, of the duties associated with maintaining the asset. The actual cost of O\&M incurred by the owner is reflected in the PPA or lease price.

\footnotetext{
${ }^{10}$ Utility-scale solar installations also commonly sell power to utilities and other purchasers through PPAs. However, these more closely parallel the contracts that independent power producers execute to sell energy in the power markets. Bringing the PPA to consumers and businesses that do not transact in the power markets was an additional innovation beyond the mere application of an existing contractual framework to the solar industry.

${ }^{11}$ Regarding the solar commercial market, NREL internal data from select state incentive programs suggest that TPO has been a large part of several markets since 2007, though because of considerable variations in state markets and incomplete data sets, no comprehensive analysis is available for the commercial segment.
} 


\section{TPO Business Models: Aggregated vs. Disaggregated}

SolarCity and Sunrun were the first two TPO companies to begin operations in the residential market in the United States after the ITC was made available to solar technologies in 2006 . These firms set up large funds-special purpose vehicles which are used to finance and hold the assets, just as in a project finance deal-with tax equity investors through which they financed the installation of many small residential systems and some mid-size commercial systems.

As of this writing, at least 10 other companies have come to market with lease and PPA products since that time, all of which employ the same method of creating large tax equity funds through which to deploy a large number of solar systems. However, the differences between the SolarCity and the Sunrun business models in 2006 exemplify a fundamental split in the TPO market today. SolarCity began as a largely integrated company, with its own sales, financing, installation, and O\&M segments (SolarCity is even more integrated today-it owns its mounting technology and a capital-raising platform, and has plans to manufacture its own modules in the near future). In contrast, Sunrun ran a more disaggregated business, where the company engaged in sales and financing/ownership of the solar assets, but outsourced installation and O\&M to partners.

Sunrun has since acquired an installation company to consolidate its position, but there are still companies in the market today that maintain a disaggregated model. Clean Power Finance, for example, began financing systems in 2011 with a "white label" product (a PPA that individual installers could brand as their own) and has largely preserved its financing-only model to date (Clean Power Finance 2012). It outsources all other aspects of the TPO process, such as sales, and installation to its partners (Litvak 2014).

\subsubsection{Third Party Ownership and Public Sector Procurement}

The U.S. public sector represents a significant market for the solar industry, in large part because some governments (at the federal, state, and local levels) set renewable energy goals that mandate procurement of renewable energy for agencies under their purview. The U.S. government, for example, has announced a series of environmental and sustainability goals, most recently in a March 2015 Executive Order, which calls for (among other measures) federal agencies to derive $30 \%$ of their electricity from renewable sources by 2025 (DSIRE 2015d). ${ }^{12}$ The federal government is the single largest consumer of electricity in the United States and can therefore support a significant amount of DGPV deployment through its internal mandates. The U.S. Department of Defense, the single largest consumer of energy within the federal government, also has its own goals, which include $1 \mathrm{GW}$ of renewable energy deployment for branches of the military (Air Force, Army, and Navy) on bases and installations (ACORE 2014).

State renewable energy goals are also commonly promulgated in gubernatorial executive orders (in addition to RPSs), which direct state agencies (sometimes non-bindingly) to install renewable energy or energy efficiency technologies at their facilities. These orders are often carried out via special governmental programs (often called "Lead by Example" or LBE) that provide technical and sometimes financial assistance to facilitate the achievement of directives (ACEEE 2015). Local governments have authority to set goals and pursue implementation within their jurisdictions. The city of Boulder, Colorado, for example, is actively seeking the establishment

\footnotetext{
${ }^{12}$ The order specifies that this target is only to be met where the renewable technology is "life-cycle cost effective." Also, the order calls for incremental progression, with intervening percentages to be achieved every two years (DSIRE 2015d).
} 
of its own municipal utility in an effort to accelerate a transition to cleaner sources of electricity generation (City of Boulder 2015).

Most governmental entities will contract with third parties to procure DGPV electricity via a PPA instead of owning the assets themselves. As discussed in Section 4.2, PPAs can offer several advantages, including the avoidance of large capital outlays (for purchasing assets), O\&M provision, and efficient monetization of incentives. The last is a particular draw for public agencies in the United States (which, in addition to governments, also include schools, nonprofits, public and nonprofit hospitals, and others), as these entities cannot access the value of the federal tax benefits as majority equity holders. However, as power purchasers, they can access this value by allowing a private entity with tax capacity to own the generation assets and thus receive a reduced price per kilowatt-hour of electricity.

Federal, state, and local governments are attractive customers for solar energy providers because these are highly creditworthy entities that bear low risk of defaulting on their contracts. Accordingly, PPAs with government entities are, typically, easily financeable. That is, financiers of solar assets can be reasonably assured of meeting their returns in the specified timeframe and obtain relatively low risk-adjusted rates on the financing terms.

In contrast, PPAs executed with private counterparties can be riskier for solar energy providers because the probability of default is generally higher in the private sector, especially amongst smaller entities or commercial entities that have limited access to capital. There are 28 million "small businesses" (U.S. Small Business Administration 2015). Relatively few businesses in this class are rated by a nationally recognized statistical ratings organization (such as Standard \& Poor's or Moody's), which means that tapping the majority of the American business community as offtakers of solar energy can be a significant challenge for the solar industry.

\subsection{Solar-Secured Loans}

As distinct from a TPO, solar-secured loans offer a means of PV ownership to consumers, and a means to capture some of the benefits (such as potential increase in home value and direct receipt of the ITC). Examples of secured lending have long existed in other asset classes, such as automobiles (auto loan) and housing (mortgages), but the model has only recently been applied in the solar market. A lender extends credit to a consumer to finance the consumer's purchase of an asset (e.g., a solar system). The lender then takes a security interest in that asset which gives them the power to reclaim the asset in case the consumer defaults on the loan agreement. Until financiers in the solar industry adopted secured lending, much of the debt that consumers used to purchase solar systems came in the form of second mortgages, or specialty loans (e.g., the U.S. Department of Housing and Urban Development's PowerSaver loan or one-off unsecured loans underwritten by banks at the request of customers).

\footnotetext{
${ }^{13}$ The U.S. Small Business Administration generally defines a "small business" as one either having 500 jobs or fewer in the mining or manufacturing industries or $\$ 7.5$ million or less in annual receipts for non-mining and manufacturing (U.S. Small Business Administration 2014).
} 
In early 2014, Sungage Financial entered the residential solar market with the first solar loan product that was secured by the assets which it funded. Previously, if homeowners decided to take out a loan to purchase a solar system, they would typically borrow against their home equity or leverage their relationship with a bank or credit union to underwrite a one-off loan (a third option could be a PACE loan—see Section4.3.1). In the first case, the loan to finance a solar system purchase would be secured by the real estate as a second mortgage; in the second, the lender might not take a security interest in any collateral. The innovation in Sungage's product was that their loan product gave the lender recourse to the solar system alone, thereby avoiding the complications of being subordinate to a primary mortgage while still allowing for a competitive interest rate as compared with an unsecured loan (Feldman and Lowder 2014).

There are several variations of loan products available in the United States today. SolarCity has a 30-year loan product in which payments are not necessarily based on a principal and interest calculation, but on energy generated (i.e., as in a PPA). Most other providers will offer a 10- to 20-year loan that amortizes more like a typical consumer loan (e.g., car loan or credit card) offered at interest rates that will vary by customer credit score, buydowns from the installer, and other factors. O\&M for these systems will either come from the solar company that originated the loan (e.g., SolarCity), from a service partner (e.g., Enphase performs O\&M on Clean Power Finance's portfolio of solar loans), or from an approved solar contractor. In the case of a home sale, the homeowner will usually be required to pay down the remaining balance of the loan, but other options could be possible (e.g., an assignment to the new homeowner, or possibly a transfer of the solar assets to the new property).

Since Sungage launched their loan product, most solar TPO providers have brought their own solar-secured loan products to market. Some analysts believe that solar loans, because of the economic advantages they may afford to consumers, will begin to gain significant market share relative to PPAs and leases in 2015 (GTM/SEIA 2015). In some cases, systems financed through loans can impose a lower cost of capital on system hosts relative to PPAs and leases (current market interest rates can vary from $2.99 \%$ to $8 \%$ compared to upwards of $9 \%$ cost of capital for TPO systems). Loans also allow hosts to own the systems themselves (Feldman and Lowder 2014). Some additional benefits of ownership include:

- Receipt of the ITC (Section 25D of the tax code allows for individuals to receive the 30\% ITC, though this will expire completely in 2017, while the Section 48 credit for businesses scales down to $10 \%$ )

- An increase in home value

- "Free" solar electricity once the system is paid off. When a TPO contract ends, the host must still buy the asset or sign a new PPA or lease contract (or request system removal).

Solar loans have largely been made possible by the decreasing system costs discussed in Section 2. In some cases, the total installed cost of a residential systems have dropped below $\$ 3$ per watt, which would allow an average $6 \mathrm{~kW}$ system to be priced at less than $\$ 20,000$ (SolarCity 2015). A loan with a $\$ 20,000$ principal and a 20 -year amortization period will yield a 
monthly payment that can compete with the monthly avoided cost of retail electricity in several states as well as with the monthly cost of a PPA or lease. ${ }^{14}$

\subsubsection{Property Assessed Clean Energy}

PACE is another loan option to finance PV installations as well as energy efficiency upgrades on residential and commercial properties. PACE distinguishes itself because it involves a special tax assessment on the host's property. The amount of that assessment will be made to the property owner through a loan (either issued by the municipality in which the property owner lives, or more commonly by a private lender). The property owner uses the loan to finance the energy upgrades, and then pays the loan down via his/her property tax bill.

Because PACE loans are secured via a tax assessment-which is senior ${ }^{15}$ to the property mortgage and transfers to new owners when the property changes hands - the likelihood of payback is very high. In other words, the credit profile of PACE loans can be especially attractive to potential lenders and bond investors. However, the Federal Housing and Finance Agency (FHFA), the entity that regulates the two U.S. government-sponsored mortgage holders Fannie Mae and Freddie Mac, has opposed residential PACE (it does not regulate commercial mortgages) because it subordinates the position of the primary mortgage lender. In May of 2010 Fannie Mae and Freddie Mac made statements that they would no longer purchase mortgages with PACE obligations attached to the property, and this virtually froze residential PACE activity across the United States. The state of California subsequently filed a lawsuit against the FHFA, but the case was never settled. Consequently, there is still uncertainty in the marketplace about residential PACE loans that have first-lien status.

In August of 2015, the White House released a fact sheet that provided some detail on the Administration's intention to remove barriers to PACE programs to "unlock alternative sources of capital to accelerate renewable energy and efficiency retrofits for households, and reduce energy costs for consumers" (White House 2015). The White House indicated that the Department of Housing and Urban Development (HUD) will issue guidance that will clarify what types of PACE loans are eligible for Federal Housing Administration Insurance (a key element to keeping mortgage rates low for homeowners) and how the transfer of PACE liens can proceed in a home sale. These guidelines are, as yet, unavailable, and may only apply to PACE liens that are subordinated to the mortgage (second-lien status).

Despite the FHFA's position, residential PACE activity has continued in California, most notably through the Home Energy Renovation Opportunity (HERO) program, a partnership between Renovate America, the Western Riverside Council of Government, and the San Bernardino Council of Government. As of May 2015, the HERO program has underwritten over \$470 million of residential projects, most of which were for energy efficiency upgrades, for some renewable energy and a small portion for water conservation projects (KBRA 2014a; KBRA 2014b; KBRA 2015a). In 2013, California's governor Jerry Brown announced a \$10 million fund that the state has put in reserve to compensate Fannie Mae and Freddie Mac for any lost

\footnotetext{
${ }^{14}$ For more information on this comparative loan analysis see Feldman and Lowder 2014.

${ }^{15}$ In other words, if the borrower goes into bankruptcy or experiences some other kind of credit distress (late payments, etc.), the PACE lender will be the first to receive recoverable funds, even before the mortgage holder.
} 
revenues from foreclosures to help mitigate the financial risk to PACE lenders. The FHFA, however, has indicated that this is not an adequate size fund to cover their risk exposure (KBRA 2015a).

\subsection{Financing Innovations}

Following the successful implementation of third-party-owned systems, several types of financing mechanisms have been developed to support the increased need for capital. These financial innovations are anticipated to both increase the amount of capital available for renewable energy projects as well as lower the associated costs of financing.

\subsubsection{Securitization}

Securitization is the process by which financial assets (e.g. contracts such as leases and loans which stipulate cash transfers between parties) are pooled and processed into financial vehicles (securities), which are then sold to investors. This process not only confers liquidity by providing investors a standardized, tradable product, but it can also reduce various risks associated with the individual assets through the protection that diversification affords (Lowder and Mendelsohn 2013).

Securitization has been a fixture of the U.S. mortgage markets since the 1970s and has come to represent a significant portion of the refinancing in other asset classes since (e.g., auto loans and leases, credit card debt, student loans, equipment leases, etc.). Generally, any asset that generates a steady stream of cash flows can be securitized, provided that there are enough of them in a pool to meet investors' appetite for investment size, and the risk is sufficiently low to make the cost of capital advantageous to the issuer of the securities.

Issuing securities against cash-flow-generating assets can provide several benefits for companies, including increased liquidity of the assets, refinancing at lower rates, and risk reduction. Table 2 presents a more comprehensive list of benefits. 
Table 2. Benefits of Securitization ${ }^{16}$

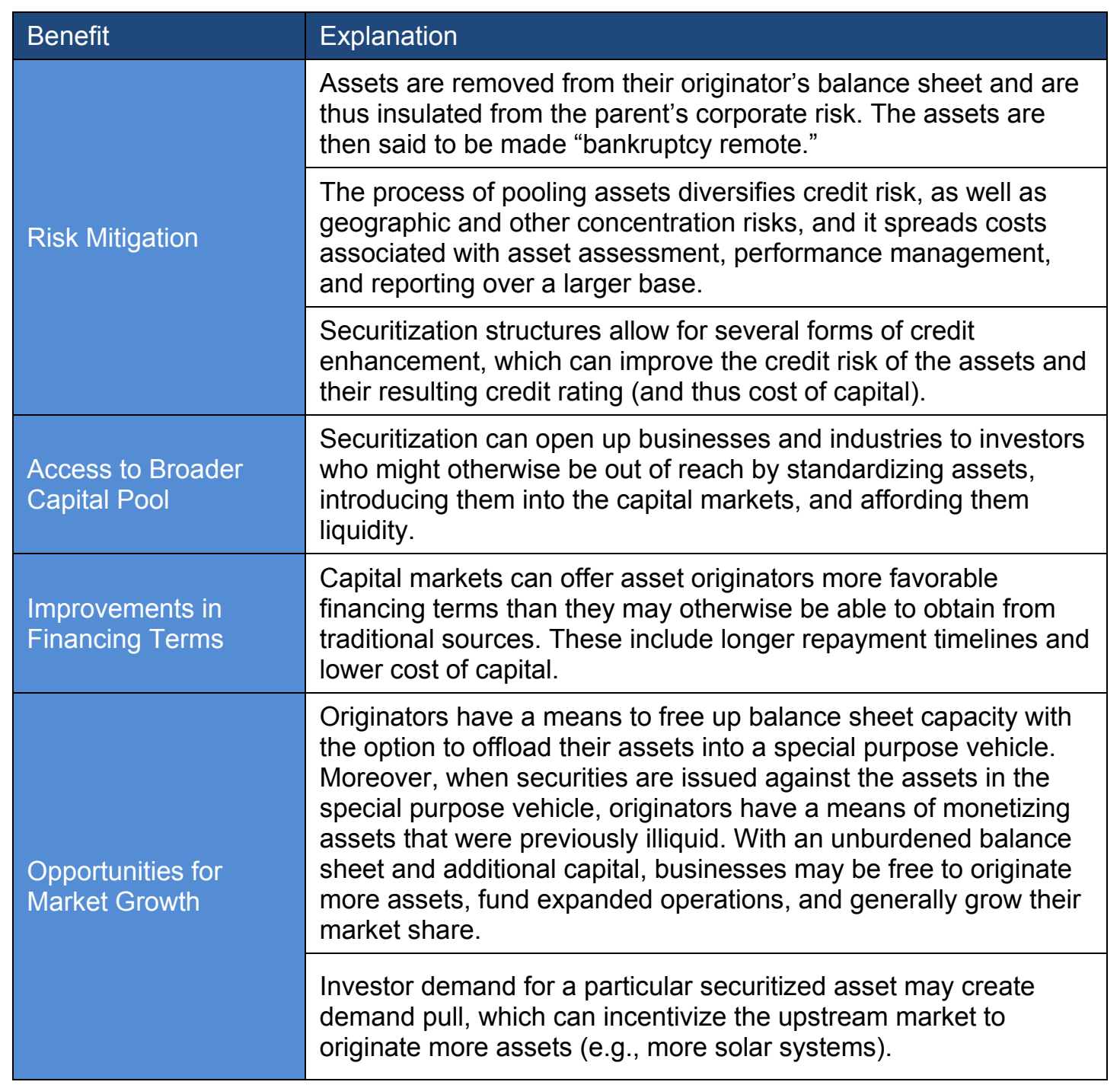

Source: Lowder and Mendelsohn 2013

One of the principal goals for executing securitization transactions is to achieve a lower cost of capital on the assets - essentially, to refinance at a lower rate. In the solar industry, refinancing at a lower rate would reduce the issuer's overall costs, and they would theoretically pass these savings through to their customers in the form of a lower cost of solar energy on their products (leases and PPAs).

To date, only two solar companies have issued solar asset-backed securities: SolarCity and Sunrun. SolarCity has had three offerings, and the terms of each successive deal have improved

\footnotetext{
${ }^{16}$ There are also several risks associated with securitization as evidenced by the central role it played in the 2008 financial crisis. However, it was less the technique itself that brought on the crisis than its abuse. Securitization remains today a fixture of the U.S. financial markets, and now include regulatory changes instituted since the 2010 Dodd Frank legislation that have targeted abusive practices and misaligned incentives (Lowder and Mendelsohn 2013).
} 
markedly, indicating that the capital markets are becoming comfortable with the solar asset class. The first SolarCity deal, offered in November of 2013, received an interest rate of $4.8 \%$ and was $62 \%$ leveraged (i.e., $38 \%$ of the assets in the portfolio were not advanced as collateral, but instead withheld as a reserve fund). The subsequent two deals received $4.59 \%$ and $4.32 \%$ and were leveraged at 66\% and 73\%, respectively (S\&P 2013; S\&P 2014a; S\&P 2014b). The Sunrun deal, which came to market in May 2015, had a blended interest rate of $4.4 \%$ between its two tranches and a leverage ratio of 75\% (KBRA 2015b).

Other solar companies are anticipated to access the capital markets through securitization in the coming years. Notably, Renovate America, the Property Assessed Clean Energy (PACE) administrator discussed in Section 4.3.1, has issued three rounds of securities itself, each backed by the tax assessments that have been made on the properties of Home Energy Renovation Opportunity (HERO) Program-participating homes. These securities are not entirely solarbacked, although they have achieved the same purpose for Renovate America as they have for SolarCity and Sunrun - to free up balance sheet capacity to originate new assets and refinance seasoned assets at favorable rates.

Achieving the lower cost of capital required to finance solar development is one particularly effective pathway to reducing the overall cost of solar energy. With the scheduled ITC reversion to $10 \%$ on January 1,2017 , solar companies are looking for ways to cut costs and keep their products competitive against traditional sources of electricity-securitization offers one means of doing so.

\subsubsection{Yieldcos}

A yieldco is a corporate entity (a limited liability corporation, limited liability partnership, or joint venture) that aggregates a portfolio of energy assets against which ownership shares-i.e., stock or units - are sold. Yieldcos are commonly "spun-off" from larger developers (e.g., NRG, SunEdison, Abengoa, etc.) to hold and generate additional value from operating assets. As subsidiaries, yieldcos will get a right-of-first-offer for projects developed by their parent companies. This gives the parents a tailor-made means to sell completed projects and redeploy their capital. As of this writing, there are at least eight yieldcos listed on the North American exchanges: NRG Yield, TransAlta Renewables, Pattern Energy Group, Abengoa Yield, NextEra Energy Partners, TerraForm Power, TerraForm Global, and 8point3 (a joint yieldco between SunPower and First Solar). Several more yieldcos have been reported to be in the stages of launching an initial public offering, though many of these may not come to fruition.

Yieldcos feature only one layer of taxation because the accelerated depreciation benefits (MACRS) of the renewable energy assets in the portfolio generate enough favorable tax benefits to offset corporate-level tax (leaving only the tax on distributions to shareholders) (Urdanick 2014). This structure is partly modeled after real estate investment trusts REITs and master limited partnerships (MLPs), two investment vehicles that are responsible for the financing of a significant portion of real property and fossil fuel assets, respectively, in the United States. As of the beginning of 2015, the two asset classes had a combined market capitalization of over $\$ 1$ trillion (Yorkville Capital Management 2015; REIT.com 2015). However, restrictions in the U.S. tax code (for REITs) and federal law (for MLPs) complicate or prohibit the inclusion of renewables in these investment vehicles (Feldman and Settle 2013). Renewables developers consequently innovated the yieldco model as an alternative to these established structures. 
The principal draws for investors are the single layer of taxation, the long-term predictable cash flows (according to Bloomberg New Energy Finance data, the vast majority of yieldco assets are contracted for 20 years and over), stock appreciation, and the promise of dividend growth. Regarding this last point, yieldcos are continually expanding their asset base to meet growth targets by acquiring primarily operating projects or project portfolios. The pace of acquisitions has been brisk over the last two years: as of July 2015, over $9 \mathrm{GW}$ of renewable assets have been acquired by yieldcos (Benson et al. 2015; Lacey 2015; K. Martin 2015). Most of that capacity has been in the United States and Canada, but several yieldcos have begun purchasing projects across the world, including from Latin America, India, China, and Europe.

One of the principal draws for developers in launching a yieldco is in the lower cost of funds they can obtain to finance their assets relative to other sources of capital. Investor yields can range from $4 \%-10 \%$; if yieldcos can raise capital in the middle of this range, then their cost of funds can be less expensive than debt raised at level of the yieldco's corporate parent (Konrad 2015; Reynolds 2015).

The renewable energy yieldco model is just over two years old as of this writing (NRG Yield, the first yieldco, went public in July of 2013) and for much of its history it has been a success story. As of June 2015, yieldcos had raised over $\$ 6$ billion in equity capital on the public markets and all were trading above their initial public offer price (Benson et al. 2015; C. Martin 2015). However, since late August of 2015, yieldco equity prices have begun a slide, most dramatically in SunEdison's TerraForm Power yieldco, which was down $49 \%$ year to date as of October 1 , 2015 (Poszywak 2015). This downturn owes to several factors, including macro-level conditions such as general turmoil in the U.S. stock market (and the energy sector particularly), and microlevel factors such as a reevaluation among investors of the yieldco model. Underlying risks such as a rise in interest rates, project availability for acquisitions, and long-term yieldco profitability are forcing what some analysts regard as a market correction for yieldco share prices. At present, it is not clear what implications this correction will have on the broader solar market. 


\section{Reducing Risk and Financing Cost: Solar Access to Public Capital Project (SAPC)}

Along with increasing the supply of capital from financing innovations, reducing the perceived risks of DGPV can also achieve many of the same benefits. In particular, reduction in risks of DGPV can result in lower financing costs. Standardization and data availability are two critical components for investors to offer reduced financing costs, especially in the context of asset securitization. Standardization of solar energy projects, including technology, contracts, and other aspects, allows for multiple projects to be pooled together into a single investment vehicle and reduces the amount of due diligence into every project.

In 2012, NREL convened the Solar Access to Public Capital working group with funding from the U.S. Department of Energy's SunShot Initiative, to drive these developments in the residential and commercial solar sectors. Solar Access to Public Capital-a consortium of over 450 organizations in the solar, finance, legal, regulatory, analytics, and other stakeholder industries-has produced standard documents for residential and commercial leases and PPAs (a loan document is in the draft stage as of this writing).

Additionally, Solar Access to Public Capital has generated a rubric of best practices and guidelines for the installation and O\&M of DGPV to promote investor confidence in the assets cash flows and to protect consumers from unsound business practices. Regarding data, Solar Access to Public Capital incubated the Open Source Performance and Reliability Clearinghouse, a database of over 3,800 DGPV systems across the United States to help benchmark PV performance and substantiate the link between energy generation and investor returns. See the Solar Access to Public Capital (https://financere.nrel.gov/finance/) and Open Source Performance and Reliability Clearinghouse (http://sunspec.org/sunspec-osparc/) websites for more information.

\section{Interconnection}

Interconnection encompasses the legal rules and procedures for generators to connect to the electric grid (Freeing the Grid 2014). These standards are typically created by PUCs for the purpose of ensuring the safety and reliability of the electricity system as new sources of energy are brought online. The relative ease or difficulty inherent to interconnection of a PV system to the distribution grid can be a critical factor in the successful development of DGPV resources.

In the United States, PV installers must first obtain a building and electrical construction permit from the local jurisdiction as well as utility approval for interconnection. Both utility interconnection and local building permitting requirements differ across states and jurisdictions, often complicating compliance for PV developers who work across a wide geographic area (see Figure 6). In addition, the level of coordination between these parallel utility and local jurisdiction approval processes can vary significantly depending on the jurisdiction. Given these variations in requirements and the level of regulatory process coordination across utilities and building-permitting jurisdictions, PV installers often experience delays following their submission of an interconnection request to the local utility. These delays can affect project timelines and therefore budgets, and, in the case that additional utility impact studies are required, can subject installers to additional costs (Ardani et al. 2015). 


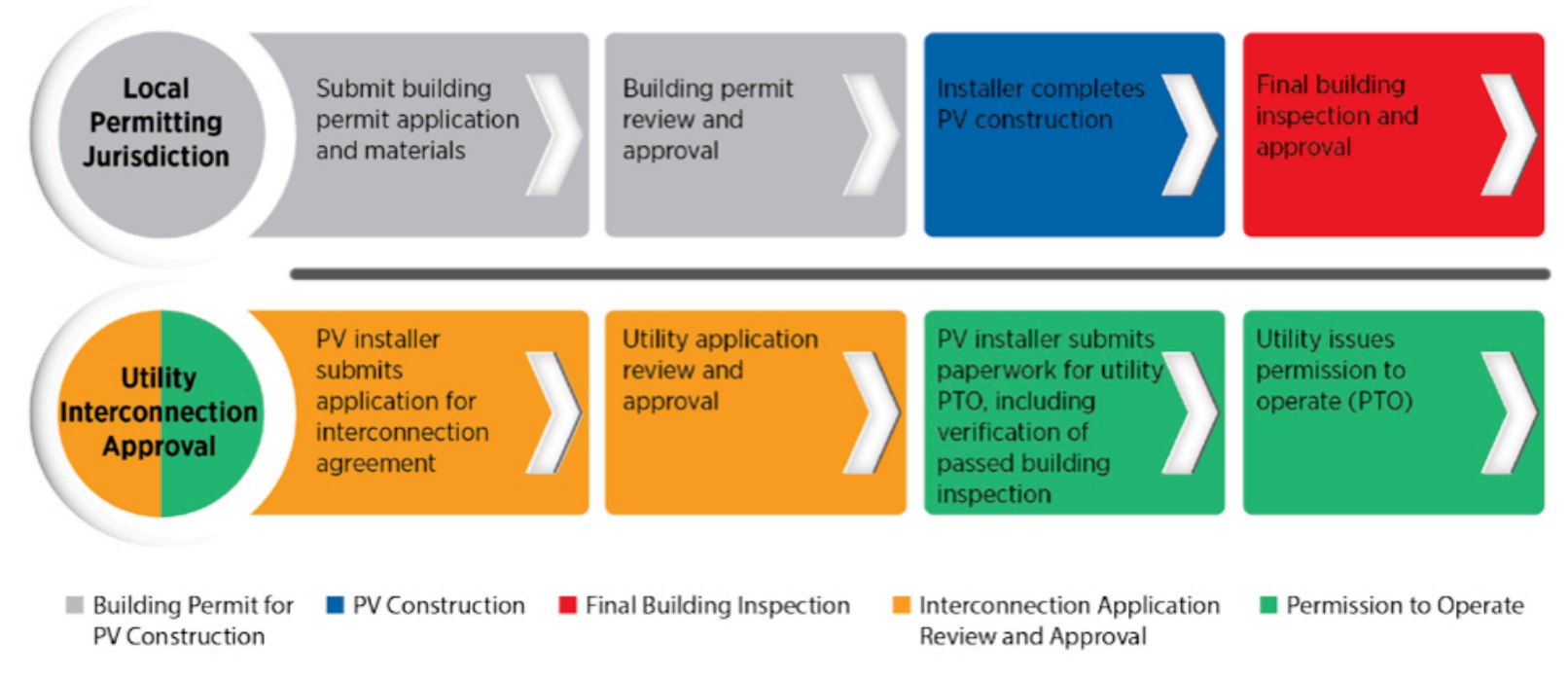

Figure 6. Process for PV building permitting and interconnection

Source: Ardani et al. 2015

To mitigate these complications and support the deployment of distributed energy resources on their networks, several PUCs have adopted standards that facilitate the interconnection process. These standards include defined timelines and expedited procedures for smaller generators unlikely to cause negative grid impacts, as well as standard agreements. Some state PUCs have also enabled more streamlined DGPV interconnection by identifying points of interconnection on the distribution grid where PV will provide locational benefits, such as avoided congestion, better management of power flows, and deferred transmission and distribution infrastructure investments (IREC 2009).

Many of the model interconnection procedures that PUCs review in establishing their own regulations come from four templates: The Federal Energy Regulatory Commission's Small Generator Interconnection Procedures (FERC 2015); the Mid-Atlantic Distributed Resources Initiative (MADRI 2015); California's Rule 21 (CPUC 2015); and the Interstate Renewable Energy Council's model interconnection standards (IREC 2013). These templates all vary in their prescriptions, but according to IREC (2009), the high-level commonalities include:

- Coverage of all technologies, rather than just renewable technologies

- Interconnection of systems up to at least $10 \mathrm{MW}$

- Pro forma interconnection agreements

- A simplified procedure for small solar arrays covering most residential installations

- A fast track procedure for systems up to $2 \mathrm{MW}$ that allows interconnection without additional cost or delay if certain screens are met

- A scoping meeting if screens are not met to review expected costs and duration of studies

- A three-part study (feasibility, impact, and facilities) process for interconnection of more complex and larger systems (CA Rule 21 has supplemental review process as a first step for systems that do not meet all the screens and, failing that, a single study process that essentially includes the three study areas listed) 
- Comprehensive coverage of issues such that utility discretion to create substantive additional rules is largely foreclosed.

Interconnection standards address a very specific piece of DGPV market development, but they are critical. Without a body of rules that explicitly facilitates the process, then DGPV generators may not be able to come online once construction is finished. This kind of lag can strand investments, endanger project economics, and generally hobble market growth. 


\section{Conclusion}

DGPV has achieved unprecedented levels of penetration in the United States from under $2 \mathrm{GW}$ in 2009 to over $8 \mathrm{GW}$ by 2014 (Figure 1) through a combination of top-down and bottom-up strategies, aided by overarching factors such as the international price decline for PV panels and advancements along the learning curve in early-adopting countries, such as Germany. A combination of federal tax policies, state mandates and incentives, business model and financial innovation have combined to enable the DGPV market successes.

This portfolio approach has generated its share of complexities, however. It has created pockets of market activity with varying fundamentals, in lieu of a single, national, unified, and standardized DGPV market for a county with legal jurisdictional differentiation as in the United States. This can be a challenging and costly for solar developers who must understand the policy, business, legal, and financial environment of each market they choose to enter. Moreover, it exposes developers to a broad set of risks. This is particularly evident as revisions to net metering are developing in over 20 states: as each PUC determines how it will reform net metering, developers will have to reconfigure the way in which they have done business for several markets, as well as risk losing some markets.

Additionally, as DGPV becomes more mainstream, friction from other industries may grow, including utility scale generators and load service entities, mortgage banking, fire safety, building codes, standards setting organizations, and others. Some states have sought to alleviate these frictions with their own strategies, but there are currently no national-level strategies. The U.S. Department of Energy's SunShot Initiative has directed several million dollars to creating national-level strategies to facilitate DGPV's interaction with existing industries and practices, although as yet, these are market-based approaches and are not codified in policies.

Challenges aside, the United States has seen consistent growth in its DGPV markets, with anticipated gigawatt-scale deployments year-over-year, at least until the ITC reversion, although some suggest robust medium and long-term markets after the ITC current expiration date. The range of policies and strategies that have, in combination, promoted this growth comprise a body of lessons learned and best practices that can be selectively applied in other countries to stimulate their own DGPV markets. 


\section{References}

ACEEE (American Council for an Energy-Efficient Economy). 2015. "State Government Lead by Example." Accessed July 13, 2015. http://aceee.org/sector/state-policy/toolkit/lbe.

ACORE (American Council on Renewable Energy). 2014. Renewable Energy for Military Installations: 2014 Industry Review. Washington, D.C.: ACORE. Accessed July 13, 2015. http://www.acore.org/files/pdfs/Renewable-Energy-for-Military-Installations.pdf.

Ardani, K., C. Davidson, R. Margolis, and E. Nobler. 2015. State-Level Comparison of Processes and Timelines for Distributed Photovoltaic Interconnection in the United States. Golden, CO: National Renewable Energy Laboratory. Accessed July 10, 2015. http://www.nrel.gov/docs/fy15osti/63556.pdf.

Ardani, K., D. Seif, R. Margolis, J. Morris, C. Davidson, S. Truitt, and R. Torbert. 2013. NonHardware ("Soft") Cost-Reduction Roadmap for Residential and Small Commercial Solar Photovoltaics, 2013-2020. Golden, CO: National Renewable Energy Laboratory. Accessed July 10, 2015. http://www.nrel.gov/docs/fy13osti/59155.pdf..

Barbose, Galen. 2014. "Renewable Portfolio Standards in the United States: A Status Update." Presentation by Galen Barbose to the Renewable Energy Markets 2014 Conference. December 4. Berkeley, CA: Lawrence Berkeley National Laboratory. Accessed July 10, 2015. http://emp.lbl.gov/sites/all/files/2014\%20REM.pdf.

Behar, M. 2009. "Selling the Sun." OnEarth, February 27. Accessed June 3, 2015. http://archive.onearth.org/article/selling-the-sun?page=2.

Benson, G., S. Unger, and M. Tan. 2015. "The Rise of the Yieldco: Emerging Considerations for Sponsors and Yieldco Investors." Clean Energy USA Finance Guide 2015, $2^{\text {nd }}$ Ed. London: Clean Energy Pipeline. Accessed June 4, 2015. http://cleanenergypipeline.com/Resources/CE/ExpertGuides/CleanEnergyUSAFinance Guide2014Edition.pdf.

Black, A. (2009). Economics of Solar Systems for Consumers: Payback and Other Financial Tests. Ongrid.net. Accessed August 28, 2015. http://www.ongrid.net/papers/PaybackOnSolarSERG.pdf.

Bolinger, M. 2014. An Analysis of the Costs, Benefits, and Implications of Different Approaches to Capturing the Value of Renewable Energy Tax Incentives. Berkeley, CA: Lawrence Berkeley National Laboratory. Accessed June 3, 2015. http://emp.lbl.gov/publications/analysis-costs-benefits-and-implications-differentapproaches-capturing-value-renewable.

Chadbourne \& Parke LLP. 2008. "Calculating How Much Tax Equity Can Be Raised: Developers of Renewable Energy Projects Struggling to Calculate how Much Tax Equity can be Raised." Project Finance Newswire. Accessed June 1, 2015. http://www.chadbourne.com/CalculatingHowMuchTaxEquity_Jun08 project finance/. 
. 2013. "US Tax Changes Start to Take Shape: MACRS Depreciation, Pooled Depreciation, Corporate Tax Reform, International Tax Reform, Subpart F, PFICs, Foreign Tax Credits." Project Finance Newswire. Accessed June 1, 2015. http://www.chadbourne.com/USTaxChangesStarttoTakeShape_projectfinance/.

. 2015. "Solar Tax Equity Market: State of Play." Project Finance Newswire. Accessed June 1, 2015. http://www.chadbourne.com/Solar-Tax-Equity-Market-State-ofPlay projectfinance/.

City of Boulder. 2015. "Energy Future Home.” Accessed July 12, 2015. https://bouldercolorado.gov/energy-future.

Clean Power Finance. 2012. "Clean Power Finance, Morgan Stanley Solar Solutions Corp. and Main Street Power Announce Largest Consumer Residential Solar Lease Facility in U.S." Press release. Accessed June 4, 2015. http://www.cleanpowerfinance.com/about-us/mediacenter/press-release/clean-power-finance-ms-solar-solutions-corp-and-main-street-powerannounce-largest-consumer-residential-solar-lease-facility-in-u-s/.

Coughlin, Jason, Jennifer Grove, Linda Irvine, Janet F. Jacobs, Sarah Johnson Phillips, Leslie Moynihan, and Joseph Wiedman. 2010. A Guide to Community Solar - Utility, Private, and Non-profit Project Development. Washington, D.C.: U.S. Department of Energy Office of Energy Efficiency \& Renewable Energy. Accessed July 2, 2015. http://www.nrel.gov/docs/fy11osti/49930.pdf.

CPUC (California Public Utility Commission). 2015. "Rule 21.” Accessed October 22, 2015. http://www.cpuc.ca.gov/PUC/energy/rule21.htm.

CREIA (Chinese Renewable Energy Industries Association). 2015. "Study on Current Challenges to Distributed PV Development in China and Suggestions." Accessed July 12, 2015. http://www.creia.net/news/headline/3896.html.

Dai, L. 2014. "China's Solar PV Station and Distributed PV Both Facing Financing Problems." Energy Conservation and Environmental Protection.

Denholm, Paul, and Robert Margolis. 2008. Supply Curves for Rooftop Solar PV-Generated Electricity for the United States. Golden, CO: National Renewable Energy Laboratory. Accessed July 10, 2015. http://www.nrel.gov/docs/fy09osti/44073.pdf.

Denholm, Paul, Robert Margolis, Bryan Palmintier, Clayton Barrows, Eduardo Ibanez, Lori Bird, and Jarett Zuboy. 2014. Methods for Analyzing the Benefits and Costs of Distributed Photovoltaic Generation to the U.S. Electric Utility System. Golden, CO: National Renewable Energy Laboratory. Accessed July 13, 2015. http://www.nrel.gov/docs/fy14osti/62447.pdf.

DOE (U.S. Department of Energy) SunShot Initiative. 2014. Soft Costs of Solar Deployment. Washington, D.C.: DOE. Accessed June 4, 2015. http://energy.gov/sites/prod/files/2014/08/f18/2014SunShotPortfolio_SoftCosts.pdf. 
DSIRE (Database of State Renewable Energy Incentives). 2015a. "Net Metering.” Accessed July 10, 2015. http://ncsolarcen-prod.s3.amazonaws.com/wp-content/uploads/2015/04/NetMetering-Policies.pdf.

_ 2015b. "Renewable Portfolio Standards with Solar and Distributed Generation Provisions." Accessed July 13, 2015. http://ncsolarcen-prod.s3.amazonaws.com/wpcontent/uploads/2015/01/RPS-carveout-map2.pdf.

_.2015c. "Value of Solar Tariff." Accessed July 10, 2015. http://programs.dsireusa.org/system/program/detail/5666.

2015d. "U.S. Federal Government-Green Power Purchasing Goal.” Accessed July 13, 2015. http://programs.dsireusa.org/system/program/detail/1060.

EIA (Energy Information Administration). 2015. "Electric Power Monthly: Table 5.6.A Average Retail Price of Electricity to Ultimate Customers by End-Use Sector." Accessed May 28, 2015. http://www.eia.gov/electricity/monthly/epm_table_grapher.cfm?t=epmt 5 _ 6 a a.

Feldman, David, and Edward Settle. 2013. Master Limited Partnerships and Real Estate Investment Trusts: Opportunities and Potential Complications for Renewable Energy. Golden, CO: National Renewable Energy Laboratory. Accessed July 8, 2015. http://www.nrel.gov/docs/fy14osti/60413.pdf.

Feldman, David, and Travis Lowder. 2014. Banking on Solar: An Analysis of Banking Opportunities in the U.S. Distributed Photovoltaic Market. Golden, CO: National Renewable Energy Laboratory. Accessed June 3, 2015. http://www.nrel.gov/docs/fy15osti/62605.pdf.

Feldman, David, Anna M. Brockway, Elaine Ulrich, and Robert Margolis. 2015. Shared Solar: Current Landscape, Market Potential, and the Impact of Federal Securities Regulation. Golden, CO: National Renewable Energy Laboratory. Accessed June 3, 2015. http://www.nrel.gov/docs/fy15osti/63892.pdf.

FERC (Federal Energy Regulatory Commission). 2015. "Standard Interconnection Agreements and Procedures for Small Generators." Accessed October 22, 2015. http://www.ferc.gov/industries/electric/indus-act/gi/small-gen.asp.

Freeing the Grid. 2014. "Best Practices in State Net Metering Policies and Interconnection Procedures." Accessed June 25, 2015. http://freeingthegrid.org/.

Gauntlett, D., and M. Lawrence. 2015. Distributed Solar Energy Generation: Market Drivers and Barriers, Technology Trends, and Global Market Forecasts. Chicago: Navigant Research.

GTM/SEIA (GTM Research and the Solar Energy Industries Association). 2015. U.S. Solar Market Insight Report: 2014 Year in Review. Washington, D.C.: SEIA. 
Hansen, Lena, and Virginia Lacy. 2013. A Review of Solar Benefit and Cost Studies. $2^{\text {nd }}$ ed. Snowmass, CO: Rocky Mountain Institute. Accessed July 10, 2015. http://www.rmi.org/Knowledge-Center\%2FLibrary\%2F2013-13 eLabDERCostValue.

IREC (Interstate Renewable Energy Council). 2009. Connecting to the Grid: A Guide to Distributed Generation Interconnection Issues. $6^{\text {th }}$ Edition. Latham, NY: IREC. Accessed July 10, 2015. http://www.irecusa.org/connecting-to-the-grid-guide-6th-edition/.

- 2013. Model Interconnection Procedures. Latham, NY: IREC. Accessed October 22, 2015. http://www.irecusa.org/model-interconnection-procedures/.

Jones, J. 2015. GTM Research Flash Note: U.S. Solar Tariff Update. GTM Research.

KBRA (Kroll Bond Rating Agency). 2014a. HERO Funding 2014-2 Class A Notes New Issue Report. New York: KBRA. Accessed June 23,

2015. https://www.krollbondratings.com/research.

- 2014b. HERO Funding Class A Notes, Series 2014-1 New Issue Report. New York: KBRA. Accessed June 23, 2015. https://www.krollbondratings.com/research.

. 2015a. HERO Funding Trust 2015-1 Class A Notes. New York: KBRA. Accessed June 23, 2015. https://www.krollbondratings.com/research.

- 2015b. Sunrun Callisto Issuer 2015-1, LLC, Series 2015-1. New York: KBRA. Accessed June 25, 2015. https://www.krollbondratings.com/research.

Konrad, T. 2015. “Are Yieldcos Overpaying for their Assets?” Greentech Media. Accessed July 1, 2015. http://www.greentechmedia.com/articles/read/are-yieldcos-overpaying-for-theirassets.

Lacey, S. 2015. “SunEdison's Yieldco Acquires \$2 Billion of Wind Projects from Invenergy.” Greentech Media. Accessed July 10,

2015. http://www.greentechmedia.com/articles/read/sunedisons-yieldco-acquires-2-billionin-wind-projects-from-invenergy.

Lazard. 2014. Lazard's Levelized Cost of Energy Analysis Version 8.0. (2014). New York: Lazard. Accessed July 27, 2015. https://www.lazard.com/media/1777/levelized_cost_of_energy__version_80.pdf.

Litvak, N. 2014. Residential Solar Financing. Greentech Media Research.

Lowder, Travis, and Michael Mendelsohn. 2013. The Potential for Securitization in Solar PV Finance. Golden, CO: National Renewable Energy Laboratory. Accessed June 15, 2015. http://www.nrel.gov/docs/fy14osti/60230.pdf.

MADRI (Mid-Atlantic Distributed Resources Initiative). 2015. “About MADRI.” Accessed October 22, 2015. http://sites.energetics.com/madri/. 
Martin, C. 2015. "SunEdison Raises \$403 Million for TerraForm for Wind, Solar." Bloomberg Business. Accessed July 3, 2015. http://www.bloomberg.com/news/articles/2015-06-16/geinvests-25-million-in-terraform-global-to-expand-wind-power.

Martin, K. 2015. "Solar Tax Equity Structures." Chadbourne \& Parke LLC Project Finance Newswire. Accessed October 15, 2015. http://www.chadbourne.com/files/Publication/8f6adaf3-dacb-453c-8ea92b36c0e426c1/Presentation/PublicationAttachment/2aa3429d-f9a6-4595-9b3b2d22af00fb8c/pfn 0915.pdf.

MIIT (Ministry of Industry and Information Technology of the People's Republic of China). 2014. "2013 China Solar PV Industry Operation Information.” Accessed January 2, 2015: http://www.miit.gov.cn/n11293472/n11293832/n11294132/n12858462/15971104.html

Munsell, M. 2015. "72\% of US Residential Solar Installed in 2014 Was Third-Party Owned." Greentech Media. Accessed September 24, 2015. http://www.greentechmedia.com/articles/read/72-of-us-residential-solar-installed-in2014-was-third-party-owned.

Navigant. 2015. Distributed Solar PV: Market Drivers and Barriers, Technology Trends, Competitive Landscape, and Global Market Forecasts. Chicago: Navigant Research.

NEA (National Energy Administration). 2015. "2014 Solar PV Electricity Generation Statistics." Accessed April 9, 2015. http://www.nea.gov.cn/2015-03/09/c 134049519.htm.

Pacific Power. 2014. "Residential and Commercial Price Comparison." Accessed October 22, 2015. https://www.pacificpower.net/about/rr/rpc.html and https://www.pacificpower.net/about/rr/cpc.html.

Poszywak, A. 2015. "CreditSights: SunEdison may have hit margin call on \$410M Deutsche Bank loan.” SNL Financial. Accessed October 1, 2015.

Proctor, C. 2014. "Community solar power grows in Colorado.” Denver Business Journal. September. Accessed July 13, 2015. http://www.bizjournals.com/denver/blog/earth to power/2014/09/community-solarpower-grows-in-colorado.html.

REIT.com. 2015. “U.S. REIT Industry Market Cap.” Accessed October 22, 2015. https://www.reit.com/data-research/data/us-reit-industry-equity-market-cap.

Reynolds, Lang. 2015. “A Peek into YieldCo’s Relative Cost of Capital: An Analysis of a Recent Transaction." Golden, CO: National Renewable Energy Laboratory Finance blog. Accessed July 10, 2015. https://financere.nrel.gov/finance/content/peek-yieldco-s-relativecost-capital-analysis-recent-transaction. 
S\&P (Standard and Poor's). 2013. SolarCity LMC Series I LLC (Series 2013-1). Accessed June 23, 2015: https://www.standardandpoors.com/servlet/BlobServer?blobheadername3=MDTType \&blobcol $=$ urldata\&blobtable $=$ MungoBlobs\&blobheadervalue $2=$ inline $\% 3 \mathrm{~B}+$ filename $\%$ 3DSolarCity+LMC+Series +1+LLC+\%28Series $+2013-$

$1 \% 29+$ Presale + Nov $+11+2013$.pdf\&blobheadername2 $=$ Content-

Disposition\&blobheadervalue $1=$ application $\% 2$ Fpdf\&blobkey $=\mathrm{id} \&$ blobheadername $1=$ content -type\&blobwhere $=1244345237149 \&$ blobheadervalue $3=\mathrm{UTF}-8$.

—. 2014a. SolarCity LMC Series II LLC (Series 2014-1). Accessed June 23, 2015.

2014b. SolarCity LMC Series III LLC (Series 2014-2). Accessed June 23, 2015.

SEIA (Solar Energy Industries Association). 2015. "Distributed Solar.” Accessed June 20, 2015: http://www.seia.org/policy/distributed-solar.

SolarCity. 2015. Cost Calculation Methodology. San Mateo, CA: SolarCity. Accessed October 22, 2015. http://files.shareholder.com/downloads/AMDA14LQRE/821004871x0x841999/99386659-A86D-4581-8AEA13ADBD309EF1/SolarCity 2Q15 Cost_Memo_FINAL.pdf.

State of New York. 2015. "Reforming the Energy Vision Initiative." Accessed July 10, 2015: http://www3.dps.ny.gov/W/PSCWeb.nsf/All/26BE8A93967E604785257CC40066B91 A?OpenDocument.

Taylor, Mike, Joyce McLaren, Karlynn Cory, Ted Davidovich, John Sterling, and Miriam Makhyou. 2015. Value of Solar: Program Design and Implementation Considerations. Golden, CO: National Renewable Energy Laboratory. Accessed October 15, 2015. http://www.nrel.gov/docs/fy15osti/62361.pdf.

U.S. Small Business Administration. 2014. "Summary of Size Standards by Industry Sector". Accessed July 22, 2015. https://www.sba.gov/content/summary-size-standards-industrysector.

. 2015. "Small Business Trends, Small Business Impact!” Accessed July 22, 2015. https://www.sba.gov/content/small-business-trends-impact.

Urdanick, Marley. 2014. “A Deeper Look Into Yieldco Structuring.” Golden, CO: National Renewable Energy Laboratory Finance blog. Accessed October 22, 2015. https://financere.nrel.gov/finance/content/deeper-look-yieldco-structuring.

Wang, Lijia. 2014. "Financing Difficulties for Distributed Solar PV.” Energy (Chinese). 2014(2): $65-67$.

Wellinghoff, J., and J. Tong. 2015. "Wellinghoff and Tong: A Common Confusion Over Net Metering Is Undermining Utilities and the Grid." Utility Dive. Accessed October 15, 2015. http://www.utilitydive.com/news/wellinghoff-and-tong-a-common-confusion-over-netmetering-is-undermining-u/355388/. 
Wesoff, E. 2015. “APS Proposes \$21 Monthly Fee for Residential PV, Launches Home Energy Storage Pilot." Greentech Media. http://www.greentechmedia.com/articles/read/APSProposes-21-Monthly-Fee-for-Residential-PV-Launches-Home-Energy-Stora.

White House. 2015. "FACT SHEET: President Obama Announces New Actions to Bring Renewable Energy and Energy Efficiency to Households across the Country." Accessed September 24, 2015. https://www.whitehouse.gov/the-press-office/2015/08/24/fact-sheetpresident-obama-announces-new-actions-bring-renewable-energy.

Wiser, Ryan. 2007. "The Treatment of Solar Electricity in Renewables Portfolio Standards." Presentation by Ryan Wiser prepared for the U.S. Department of Energy. April. Berkeley, CA: Lawrence Berkeley National Laboratory. Accessed July 10, 2015. http://emp.lbl.gov/sites/all/files/PRESENTATION\%20pv-rps-set-asides-2007.pdf.

Xcel Energy. 2015. "Solar*Rewards Community - Current Program Status." Accessed July 14, 2015. http://www.xcelenergy.com/Energy_Solutions/Rebate_Finder_Tool/Solar*Rewards_C ommunity__Current_Program_Status.

Yorkville Capital Management. 2015. "MLP Asset Class Overview.” Accessed October 22, 2015. http://www.yorkvillecapital.com/asset-class-overview.aspx. 